\title{
HORSE RACING
}

\author{
BY
}

HONBLE ADMIRAL ROUS. 
TUFTS UNIVERSITY LIBRARIES

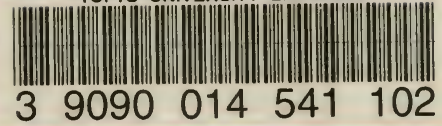





\section{ROUS ON RACING.}



ON THE

\section{LAWS AND PRACTICE 7}

\section{HORSE RACING,}

ETC. ETC.

EY

THE HON ${ }^{\text {BLE }}$ ADIIIRAL ROUS.

LONDON:

A. H. BAILY \& Co.,

ROYAL EXCHANGE BUILDINGS, CORNHILL.

1866. 


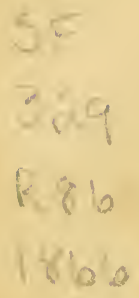

LONDUN: PIRNTED BY W. CLOWES AND SONS, STAMFORD STREET, ANU CHARING CROSS. 


\section{CONTENTS.}

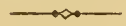

PREFACE . . . . . . . . . $\mathrm{xi}$

CHAPTER I.

On the State of the English Turf in 1865

CHAPTER II.

On the State of the Law

CHAPTER III.

On the Rules of Racing

CHAPTER IV.

On Starting-Riding Races-Jockeys .

\section{CHAPTER V.}

On the Pules of Betting

\section{CHAPTER VI.}

On the Sale and Purchase of Horses

On the Office and Legal Responsibility of Stewards . 49 Clerk of the Course . Judge Starter

On the Management of a Stud 


\section{RACING CASES.}

Horses of a Minor Age qualified to enter for Plates and Stakes . . . . . . . 65

Jockey changed in a Race . . . . . . 65

Both Jockeys falling abreast Winning Post . 66

A Horse arriving too late for the First Heat allowed to qualify . . . . . . . . . $\quad$. 67

Both Horses thrown-Illegal Judgment . • . 67

Distinction between Plate and Sweepstakes . • . 65

Difference between Nomination of a Half-bred and

Thorough-bred . . . . . . .

Whether a Horse winning a Sweepstakes, 23 gs. each,

three subscribers, could run for a Plate for Horses

which never won $50 l$. . . . . . 70

Distance measured after a Race found short . . 70

Whether a Compromise was forfeited by the Horse omitting to walk over . . . . .

Whether the Winner distancing the Field is entitled to

Second Money . . . . . . .

A Horse objected to as a Maiden for receiving Second

Money . . . . . . . . 72

Rassela's Case-Wrong Decision . . . . 73

Two Horses running by Mistake Five-and-a-quarter

Miles instead of Four Miles . . . . 75

Match starting at the Wrong Post . . . . 75

Stewards revoking their Decision after Distancing a

Horse. . . . . . . . 76

Horse taken away-Bridle not allowed in the Scale $\quad 77$

False Start, St. Leger . • • • . • • 78

Disputed False Start at Newmarket . . . . $\quad$. 79

Jockey 'Thrown after passing Winning Post . . . 80

Jockey dropping Stirrup-leather after passing Winningpost 
In making Stakes the Trainer considered as the Agent .

A Horse not considered a Winner unless he is registered

in the Official Calendar $\quad$. $\quad . \quad$. $\quad$. 82

Involuntary Jostle

Foul Riding

Foul Riding and Fighting . . . . . . . 84

A Horse Jostling and the Jockey Striking . . . 85

A Cross Claret Stakes, Newmarket . . . . 85

Complaint of Crossing not made in time . . . 86

Jostling, and allowed to Start again . . . . $\quad$. 87

Running wrong side of Post. $\quad$. $\quad$. $\quad$. $\quad$. $\quad$. 88

Running wrong side of Post, complaint not made in

time . . . . . . . . 88

One Horse driving another on the wrong side of Post . $\quad 89$

Whether the Second Horse distanced can receive

Entrance Money • • • • • • 90

All the Horses going on the Wrong Side . . . 90

Crossing York, 1848-Extraordinary Decision . . 91

A Horse Scratched obliged to pay the whole Stake . 92

Loutherbourg Case . . . . . . . . . 93

Incorrect Nomination . • • . . • . 94

Declining to receive Evidence on Misnomination . 94

Similar Case-Evidence received _ . . . . . 95

Whether a Horse was entered in time according to the

Articles . . . . . . . . 96

A Stake illegally re-opened _ . . . . $\quad$. 97

Jockey dismounting before he passed the Winning Post

allowed to start again, no objection having been made in time

Two Horses Running for a Plate belonging to same Owner

Hunters' Certificates not produced-both disqualified .

Whether a Horse, the Joint Property of the Subscriber and a Confederate not a Subscriber, can Start without paying Extra Entrance . 
A Horse not distanced because there was no distance-

A Horse disqualified from Default . . . . 102

A Horse disqualified for not making Stakes . . 102

A Horse entered after the time of closing, and winning,

because no Objection was made until after the

first Heat . . . . . . . . 104

Winning Jockey not weighed owing to a bad fall-

Horse disqualified . . . . . . . . 104

Horse disqualified owing to the Orner having a Share

in another Horse in the Race . . . . 105

Whether a Horse which wins subsequently to his entry

is to carry extra Penalties . . . . . 105

Twenty-three miles run in 57 min. 10 secs. . . 106

\section{BET'TING CASES.}

On a Double Event-Second Event compromised. . 107

A Case of Collateral Betting . . . . . 107

Winner disqualified-Second Horse gets the Bets . 108

A Double Event-Horse backed disqualified at the time-Bet void . . . . . . . 108

A Second Case of Collateral Betting . . . . 109

A Bet declared off after the Event . . . . 109

A Double Bet-First Event lost, Second off by consent 110

A Horse wrongly described-Bets void . . . 110

A Bet improperly declared off . . . . . 111

A Dead Heat-Stakes divided . . . . . 112

A Similar Case-Heats-Sweepstakes divided • . 112

A Bet lost not allowed to be paid to a Third Party . 113

A disputed Bet decided by the State of the Odds . . 114

Disputed Bet . . . . . . . . 114

A Pet, Whether any Horse ever ran a Mile in a Minute 114

A Bet upon Placing First and Second-a Dead Heat for

Second . . . . . . . . . 115 
PAGE Money given for a P.P. Bet-Horse disqualified . 116 Horses having started, Compromise of Bets repudiated 116 Tomato Case . . . . . . . . 117

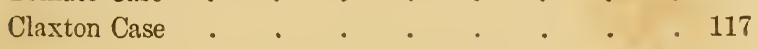

Queen's Plate Articles . . . . . . 119 Rules of Racing . . . . . . . . . 125 Rules and Orders of the Jockey Club . . . . 149 Scales of Weights for Age . . . . . . . 165 



\section{PREFACE.}

Since the publication of the Laws and Customs of Racing in 1852, the amusement of the Turf has rapidly spread wherever the British flag proclaims the Anglo-Saxon race. In America, in India, in China, the silk jacket is in request. On the Continent of Europe racing flourishes, and France, as usual, takes the lead. She deserves to triumph-no expense has been spared to procure our most valuable blood, our very best stallions, and to hire our cleverest trainers; and France has produced the best horse since the days of Bay Middleton.

"Palmam qui meruit ferat."

Every true sportsman must rejoice in the triumph of the English racehorse, the Anglo-Arabian, under any colours and in any country which may have the good fortune to possess them. Horse 
racing is a public benefit; any pursuit which produces a similarity of taste excites in an equal ratio a friendly feeling. National dislikes are owing to a faulty system of education, and to the monomania of religious intolerance. I therefore hail the extension of the sport as a general benefit to mankind, and as the medium of a more extended philanthropy. But as in all subjects there is a reverse, and as human institutions carry within themselves the germs of their own dissolution, I will not ignore the enemy which always threatens our extinction, "excessive gambling," or the obnoxious tendencies which are transparent when large sums of money are dependent upon the issue of a race. Betting on a great scale frequently produces grievous results, and the wholesome excitement of a fine race, or the patriotic inducement of improving the breed of horses, become secondary considerations.

"Nunc juvenem imparibus video concurrere fatis, Parcarumque dies et vis inimica propinquat-"

We have now arrived at the 13th and 14th generations from the imported Barbs and Arabians; there is nothing to be compared to them for speed, high courage, and stability. With a great object in view for 200 years, we have attained a 
marvellous success by adhering to one systemalways seeking the best stallions, and by confining the breed to the pure blood of the sons of the desert.

There is an ignorant notion abroad that the thoroughbreds have degenerated, because so many are broken down before they are four years old. It is no wonder, if we reflect that in these railroad times the young horses are destroyed by galloping and racing for ten months in the year, twoyear-olds running three and four times in a week. It is the old story - killing the goose for the golden eggs-otherwise there is no deterioration; on the contrary, the racehorse never was so good. When their equals are to be found, there will be an orthodox feeling for national jealousy. A very absurd crusade has been got up against light weights and short courses. Some writers condemn the system on the plea that it is a deterioration of the sport, and an encouragement to gamble. This is genuine twaddle, for as far as gambling is concerned, the more interesting the race, the more celebrated the competitors, the higher will be the speculations and the scale of betting. Racing without gambling is a hypocritical cant; every man is a gambler, whether he risks fire shilling or five thousand pounds. The 
xiv Preface.

morning papers quote the odds every Tuesday and Friday. The sporting papers encourage gambling in all its branches,-advertisements from List Houses, from touts, from prophets who never err after the horses have passed the winning post, form the principal staple of their trade; without these ingredients they could not exist. Men must play their game according to their cards. If their horses are jades, they will hold fast to short courses; if they are slow and stout, they can expatiate on the merits of the Beacon Course. It is bad policy to restrict any person in his amusements when they neither border on cruelty or injustice, and unwise legislation to forbid short races to be run at Newmarket, the policy of which has tended to increase the number of short races on the country race-courses, to the prejudice of the interests of the racing metropolis; the only excusable interference on the part of the Jockey Club was to forbid yearlings running for public stakes under the penalty of future disqualification. There was sound sense in this resolution; but as far as light weights and short courses are concerned, the lighter the weight the less chance of breaking down the horse, and the shorter the course, the oftener you can run your horses without detriment. As all the great prizes are restricted 
to long courses, every breeder tries to produce the stoutest horse. A horse which can stay two miles is worth 2,000l.; a speedy jade is not worth 2007. There is no premium more sought for than this. In racing, wind is strength; a good heart and fine lungs in a delicate frame constitute stoutness. A hunting man's definition of a stout horse is a square, well-shaped animal up to 15 stone. This class often corresponds with our speedy T. Y. C. winners, generally on a grand scale. I have heard a celebrated Nimrod remark that the stoutest hunters he had ever known were thoroughbreds, notorious for speed, which could not get beyond six furlongs at Newmarket. In following hounds, when the cocktails were galloping, they were cantering: These great horses increase in numbers every year, because we generally breed by the largest stallions. Large horses, like big men, run fast, and seldom stay a distance, but they can carry weight, and under 16 stone would beat little clearwinded horses like Tim Whiffler, over six miles, when the latter would double distance them at light weights. Horses, like greyhounds, produce three remarkable runners out of 2,000. All stoutness and speed is by comparison-the repudiated jades which win short races at light 
weights, and are condemned by critics as good for nothing, would beat the celebrated Arabs at heavy weights for twenty miles, and this is the only country in the world where their worth is ignored. Starting back to the old King's Plate weights, 12 st. 2 lbs., and four-mile heats, the system might be congenial to New Zealanders; but in these enlightened days, when cruelty to animals is at a discount, no man with the common feelings of humanity would propose to revive our ancient barbarism. 


\section{HORSE.RACING.}

\section{CHAPTER I.}

ON THE STATE OF THE ENGLISH TURF IN 1865.

THE number of horses in training has increased pari passu with the wealth of the country. They may be calculated at 2,500, exclusive of steeplechasers and the yearlings which are taken up between July and December; they have doubled in thirty-nine years. The votaries of racing may be multiplied by ten.

Although the condition of the Turf is in a prosperous state where it is protected by gentlemenfor instance, at Ascot, where there is more money actually given to be run for than on any eight country race-courses in England, because there are no deductions, fees, charges for weights and scales, or illicit sales by auction, and the entrancemoney is paid to the second horse, according to the ancient law of the land; and again at New- 
market, where no revenue is derived from racingstands, or from the public who destroy our turf by a thousand vehicles of all descriptions and by two thousand horsemen-I can name no other racecourses with grand stands, excepting Brighton, which do not enjoy a revenue very incompatible with the amount of money they actually give for racing prizes.

To meet the demands of so many aspirants for fame, or for more substantial benefits, many of the old established race-courses are re-opened to initiate second and third meetings, not for the love of sport, but for the certainty of making a good investment and a lucrative speculation. With this object, never to be lost sight of, nothing can be worse than the exactions perpetrated at most of the country meetings under the sanction of corporations of racing cities, and by the lessees of the race-courses. They are balanced by the docility of the horse-owners, who imagine, that by the assistance of the friendly handicapper-who is the clerk of the course or the lessee-they may win a great stake, forgetting that for favours to be received there may be many competitors with equal claims for light weights, and that the system of handicapping every petty plate, when the clerk of the course is master of the situation, and can 
dispense his favours without being called to account, is the bane, and will be the destruction of country races. A new source of profit has been lately introduced by the lessees of race-courses to put up to auction the winners of selling stakes and to pocket the overplus; which by the 56th Rule of racing is the perquisite of the owner of the second horse. As this is a lucrative business-14,000l. per annum paid out of the pockets of horse-ownersselling plates of a paltry amount are introduced on every occasion; winners to be sold for all prices, with allowances of weight; and the bait is very tempting to a great gambler. He enters a 500 . horse, winner to be sold for $30 l$., backs him for all the money in the ring, and then repurchases him for his real value, or makes a bargain with the lessee before the race, and the sale is fictitious. As far as the race is concerned, the moment the favourite has apparently an advantage, the other horses pull up to avoid the unenviable place of second, and the fair sportsman has no chance to win. If the Jockey Club would interpose to correct this lawless system: they might offer a compromise which would partially redress the evil, viz. by passing a law, that when winners are sold by auction, the owner of the second horse is entitled to receive a moiety of the surplus. This policy is established at the 
Brighton Club, and gives general satisfaction. Then the horses would be fairly run out to secure the second money.

One hundred and thirty years ago, so many robberies took place on the minor race-courses in England, in running for petty prizes, which are re-established in the present day, with the same result, that an Act of Parliament was passed in 1740 , to render illegal every plate under the value of $50 \mathrm{l}$, with a penalty of $100 \mathrm{l}$. to the printer or publisher of the programme, and a fine of $200 l$. for any person who started a horse for a smaller stake, excepting at Newmarket and Hambleton.

This Act was repealed in 1844, without due consideration. It was hurried through Parliament, to assist a private job, an information having been laid against an influential person for running two horses in a race, which forfeited the best horse to the informer.

What happened before, always happens again. IVe are now retrograding to wretched 307 . Plates and small prizes, and it is again advisable to renew a similar Act.

In the amusing statistics which appear in the sporting papers during the recess, no editor ventures to trespass on the forbidden ground, viz. the actual amount of money given for racing prizes in 
On the State of the English Turf in 1865. 5

proportion to the revenue received from grand stands, sales by auction, deductions from stakes, entrance money, and weights and scales. I have spoken to a gentleman of great experience connected with the press, respecting these impositions His answer was, "We dare not mention the subject, or we should lose the pecuniary advantages of publishing the programmes." Thus the interests of the horse-owners are unprotected. The receipts of the great stands at Ascot, Epsom, Doncaster, and elsewhere have increased from 50 to 75 per cent. in the last ten years. It might be considered just and politic that the stand proprietors should augment the amount of their racing prizes in proportion to their revenues; such an idea is not in unison with their domestic habits. They inherit what Caming described to be "the fault of the Dutch, giving too little and asking too much."

To illustrate my statement I will take the racing metropolis of the North, "Doncaster," so celebrated for its liberality to the Turf. In 1864 the corporation voted $1,200 l$. to the racing committee, who advertised $2,200 l$. in prizes; but then deductions from their own stakes, the entrance money, the sales by auction, weights and scales, charges for expenses from the winners of the St. Leger and Park Hill Stakes (to which they 
never contribute sixpence) amounted to $1,435 l .10 \mathrm{~s}$. -although the revenue from the stands has increased from 4,000l. to nearly 7,000l. in ten years; still the same 1,200l. is annually voted; still the old song, 200l. to the Great Yorkshire Stakes, winner to pay back 50l.; Doncaster Stakes 100l. added, winner to return 20l. for ExPENSES; ignoring the fact that they are paid twenty times over. The only improvement which has taken place is owing to some feeling of compunction, that as the racing community enriches the corporation, and pays all the rates and taxes, the authorities have at last forbidden the saints to vilify us with damnatory placards from the trees in the avenue leading to the race-course. We pay dearly for our plenary indulgence, considering the races put 50,000l. into the Doncaster pockets. At York, where they have illegally received in two years 2,138l. for sales by auction, they cannot afford to give a miserable 50l. Plate without a demand of 5 l. from the winner besides the entrance money. On all other points I willingly testify to the efficiency and to the integrity of the handicapper and the racing officials of York and Doncaster; it is not their fault that the above exactions are imposed. On other race-courses the same black mail is levied, and great concessions expected for favours con- 
On the State of the English Turf in 1865. 7

ferred. It is difficult to give up malpractices when they are lucrative. What can be in worse taste than to advertise a 100l. Plate winner to pay back 20l.? Why not have the honesty to call it an 80l. Plate? The winner of this fictitious $100 l$. carries the extra penalty for winning $100 l$. According to the 6tth Rule the deduction is not allowed. The winner is therefore doubly imposed upon.

The owner of a racehorse in the United Kingdom is like Cain, the hand of every man who profits by the trade is against him. From the moment a horse leaves home to meet his engagements, hay, oats, stabling, accommodation for the groom, rise in value 100 per cent.--imposed upon by racing committees, pillaged by the lessees, cheated by the publicans, liable to be poisoned by the sinners, and certain to be anathematized by the saints. The horse returns with a cough, or lame by running on some atrocious course, and the lad in charge, who was a trustworthy servant, is probably contaminated by the company he has associated with at the public-houses.

I have enumerated the golden nuggets which inspire clever speculators to establish races within a reasonable distance of the metropolis. With high patronage and a well attended ring, and heavy 
betting, 2,000l. may be picked up in three days by a clever handicapping lessee out of the pockets of the liberal horse-owners. It is from the public who enjoy the sport the proprietors of courses should draw their legitimate gains, and not from the owners of horses, to whom they are indebted for existence and for every shilling of their revenue, but wrong-headed racing men are always to be found, who, blind to the public good and to the interests of the Turf, conspire with the lessees to promote their own private interests. There is an old truism, that when we suffer evils to exist beyond a certain point, the remedy is at hand-wanted a Hercules to cleanse this Augæan stable. 


\section{CHAPTER II.}

ON THE STATE OF THE LAW.

THE modern improvements in racing are the assistant starter, with his flag and the Telegraph board. The latter is a necessity to the racing public, and indispensable with a large field of horses. It appears extraordinary that races should have been conducted without this necessary appendage for so many years; but the Telegraph is not a legal requirement, or alluded to in the 'Rules of Racing,' excepting when an alteration be made after the numbers are exhibited. The stewards may fine the owner, trainer, or jockey, but the stewards have no power to disqualify a winner if his number never appears on the Telegraph; and if the jockey omits or refuses to weigh before the race, or if after any false starts a horse duly entered arrives in time to take his place at the starting post, and comes in first, he is the legal winner of the race. The owner or trainer may be fined 50l. for the absence of the 
number on the Telegraph, and the jockey mulcted $10 l$. for not previously weighing by Rules $36-37$.

Errors are occasionally made by putting up wrong numbers or by an omission; the latter is freely forgiven and overlooked when it alludes to a beaten horse, but unmercifully condemned when he turns up the winner. The Ring complains when a number is taken down after that horse has been backed; this occurrence hits the fieldsmen in a non P.P. race, but sometimes it happens that a horse wins whose number has never appeared; that produces a similar despondency on the minds of the backers of the favourites. There will be no advantage to either party by twisting or altering the laws to meet these contingencies. The Tomato case at Ascot was a singular instance of the unaccountable ignorance of the 'Rules of Betting.' It was wonderful that there should have been a difference of opinion respecting the bets, when the race was officially adjudged to Tomato; it was clear as the English language could dictate, that in this instance the interests of the stakes and the bets were inseparable. It was afterwards proposed, with a view to patronize the gambling interests at the expense of the horse owners, to disqualify every horse whose number did not appear on the Telegraph fifteen minutes before 
the race; again, to fine the owner 50l. and the Clerk of the Scales 20l. whenever a mistake was made; and a gentleman proposed that if a horse's number intended to start be not exhibited or notified within fifteen minutes of the time appointed for the race, the stewards should not allow him to pass. It was likewise recommended that a box should be placed, in which written notices should be inserted, specifying the horse and jockey one quarter of an hour before the race was fixed; after that period, all the other horses engaged to be considered as having paid forfeit. Therefore if a trainer or jockey should be delayed by false starts in former races, which so constantly occurs ; or if by some trick the servants should be one minute too late-“The box is closed." Thus a horse might be disqualified from starting for a race like the Derby with a million of money at stake. Again, a gentleman proposed " that a horse whose number is on the Telegraph board shall, ipso facto, be liable to pay the whole stake, and that all bets against him should be constituted Play or Pay. The effect of this proposition would give every facility to commit robberies by putting up a horse's number without intending to start him, and then milk him to the last moment. On the other hand, if a horse cantered lame before 
starting, or met with an accident, the honest owner, in addition to his misfortune, would have to pay the whole stake. It would be insane to sacrifice the interests of the horse owner for the benefit of men with a monomania for gambling.

"Who come like shadows, so depart."

The first duty of the Jockey Club is to protect the horse-owners, who are the only pillars of the Turf-their welfare is our "summa lex;" the interests of the betting gentlemen, a very secondary consideration.

A revolution has taken place in racing during the last fifty years: formerly, the object was to win a great match, and the trial-horses ran in the handicap stakes to ascertain the relative form of the cracks, which were kept for match-makingthat is an amusement which requires a quickness of memory and a knowledge of the game. But this general system of handicapping relieves an idle man from the trouble of thinking; if a person loses a match, he may blame himself; but if his horse is beaten in a handicap, "it is the fault of that confounded handicapper," "who always lumps my horses." A handicap is intended to encourage bad horses, and to put them on a par with the 
best. It is a racing lottery - a vehicle for gambling on an extensive scale, producing the largest field of horses at the smallest expense.

A great deal of nonsense is periodically published on this subject: a gentleman, who had good horses two years ago, proposed a class legislation limiting the extent of weight to be carried by horses of the same year, which in practice would have made a large acceptance out of the question; others are horrified at the idea of an old horse winning with a light weight.

A popular handicap apparently gives every animal an equal chance to win within the limits of 9 st. $7 \mathrm{lbs}$. and 5 st. $7 \mathrm{lbs}$; we know that in the spring a bad three-year-old cannot beat a first-class old horse over a distance of ground within that margin ; that is the owner's look-out. Horses must be weighted according to the handicapper's idea of their merits, without any other regard to their age, than what he considers is commensurate with their staying qualities. There are two parties to the bargain: if the non-contents are in the majority, the handicap is a failure.

As long as gentlemen of known honour and experience will take upon themselves the unthankful task of handicapping, racing will flou rish when it gets into venal hands - when, after a race. 
the handicapping Clerk of the Course expects a bonus, there is an end to the prosperity of the Turf.

A high-weight standard is never popular; horse owners object to 9 st., although they have no objection to run in a Queen's Plate, carrying 10 st. The recent alteration of the feather-weights being raised from 4 st. $7 \mathrm{lbs}$. to 5 st. $7 \mathrm{lbs}$., puts bad three-year-olds out of court, and diminishes the field 15 per cent.

I have always been an advocate for a high scale ; in $1852 \mathrm{I}$ recommended that the Spring Handicaps should commence at 10 st. $7 \mathrm{lbs}$. Experience teaches me that, owing to the prejudices of trainers, a high standard is a certain failure with the best calculation of weights; and the Clerks of Courses well know that a light-weight handicap, like a fat horse, covers its own defects.

There is a clear conventional understanding, that when horses are engaged to run certain distances, unless they complete the whole extent, the race is void; if horses, matched to run one mile, run one mile and a quarter, the race is legal if they gallop over the course prescribed, and pass the proper winning-post: in a hurdle-race, with six rows of hurdles to be jumped, if there are only five rows placed, it is no race, but if accidentally 
seven rows are fixed, it does not detract from the legality of the issue.

It is the duty of the official authorities, the stewards included, to see that the course assimilates with the conditions prescribed, and to take care that every facility is afforded to perform the allotted task.

Although the starter has discretionary powrer to take the horses 100 yards behind the post, there is no law to limit the extension. A steward has started the horses for the Chester Cup one quarterof-a-mile before they arrived at the post. At Goodwood, 1860, the starter, after a dead-heat, took the horses to the five-furlong mark instead of the half-mile. In this instance the second horse, Walloon, would have won if they had run the prescribed course.

There is another state of the law imperfectly understood: for 150 years, horses of a junior age have been allowed to run for public money and plates, for which they are apparently excludedfor instance, Bonny Black, in 1719, won the King's Plate for five-year-old mares at Hambleton, she being four years old; Eclipse, five years, won the King's Plate for six-year olds, at Lewes, 1769 ; Bedford, three years, won the Hunter's Stakes at Bedford, 1849, carrying four years' weight. On 
this principle, which has never been disputed, a three-year-old can run for a plate for four-years and upwards, or a two-year-old can be entered for a three-year plate; the interpretation signifying they shall not exceed that age. This may be wrong in theory, and not in accordance with the articles of the race, but in practice it is harmless; if publicly known, it does not require revision.

The greatest improvement we have made at Newmarket, is the protection we have afforded to the horses, trainers, and jockeys, by surrounding the weighing-room with open iron palisades, by which means we exclude the idlers, and we aroid the noise and confusion inseparable to mixed society in a small room where silence and good order are essentially necessary to enable the Clerk of the Scales to weigh-out twenty jockeys in a limited period of time. In country race-courses this is a serious evil-the horses unsaddle in the midst of a crowd, where jostling and a transfer of loose weights may be easily made, and the weighing-rooms are crowded with persons who ought to be excluded by the police. 


\section{CHAPTER III.}

ON THE RULES OF RACING.

IN 1857 the Laws of Racing were revised; the present mode is more concise, and I am at a loss to discover any point on which a dispute can be seriously raised, or where a difference of opinion can exist in their interpretation.

The laws of racing were separated from those of betting, and a formal declaration made by the Jockey Club, Rule 10, that the Jockey Club and the stewards thereof take no cognizance of any disputes or claims with respect to bets. Here I may remark that there is a wide distinction between the interests of the Turf and the interest of betting.

I allude to the practice of a person starting two horses in a race, and declaring to win with the worst if it suits his book. This is not racing, it is an illegal conventional act to facilitate a gambling transaction; it has not a pleasing influence to see the best horse pulled up, to make way for an 
inferior companion. In 1840 the Doncaster St. Leger was won by Launcelot, and Maroon was pulled up when he could have won by fifty yards; this is a dangerous modus operandi, not sanctioned by the Joskey Club in 1838. Resolved"That it is the opinion of this Club that it is necessary to declare the extreme disapprobation of horses being started for races without the intention on the part of the owners of trying to win them," although these horses belonged to the same owner there is no rule in the book to countenance this transaction.

Another innovation was introduced in 1847, which was then, and is now, in direct violation with the 6th Rule of Racing, viz. allowing two horses belonging to the same owner to run for a plate by a special clause in the conditions-this system was established to enlarge the field, alias to increase the entrance money; it gave the owners an opportunity of declaring to win with the horse which carried the money, thereby they enjoy the satisfaction of setting the law at defiance; for without this clause both horses would be disqualified, and by the old law, the best horse would be forfeited to the informer.

The chief alterations are the specification of feather-weights, Rule 3 , the standard of which in 
the olden time was considered to be 4 st., and feathers like catch weights were not called into the scales, until it was discovered in 1841 that Tripoli carried 7 st. $5 \mathrm{lbs}$. in the Feather Plate last 3 miles B. C. ; in 1862 the standard was fixed at 5 st. $7 \mathrm{lbs}$.

Rule 40 disqualifies a horse from running if he carries less in a public race: this Rule would not affect matches. On circular courses it is a very humane regulation to protect children from the accidents incidental to racing, but at Newmarket it is superfluous legislation.

Rule 4, respecting Maidens, was until lately confined to the United Kingdom; now it extends to every country.

By rule 7, three subscribers constitute a sweepstakes, and if the number be reduced by death the race is considered a sweepstakes as long as two horses are left, the property of different persons; thus in the Juvenile Stakes at York, 1866, by the death of Mr. Osborn, only Mr. Launde's two horses remain, but Mr. L., having sold one of them with his engagements, the sweepstakes stands good.

Rule 9 raises the standard weight to $\delta$ st. $10 \mathrm{lbs}$., the original St. Leger weight being for colts, 8 st., and the Epsom Derby, 8 st. 2 lbs. 
Rule 14 forbids yearlings to run for public stakes under pain of disqualification, but this Rule does not apply to matches, which are not public races.

Rule 17.-A clause has been added to punish persons who, by fraud or misrepresentation, succeed in starting a horse after he has been legally scratched.

Rule 18 declares the nomination of a Produce Stake to be void if the mare drops her foal before the 1 st of January.

Rule 24 now applies to horses and mares which have produced winners in any country.

Rule 37.-In weighing horses before or after a race, no whip or substitute for a whip shall be allowed in the scales; and a jockey riding a beaten horse shall be fined not less than $10 l$. nor exceeding $25 \%$, if he does not return to weigh after the race.

N.B.-It has always been optional to weigh with the whip, or drop it and decline to carry it to the scales; it has been ascertained that whips loaded with quicksilver can be made to weigh 5 or 6 lbs., and exchanges have been made after the race.

Rule 38 disqualifies horses carrying more than 2 lbs. overweight without a declaration at the proper time: a due consideration is always made for 
overplus occasioned by exposure to heavy rain and mud, and the stewards are bound to admit the plea, and to give the defendants the benefit of a doubt, when there is clearly no attempt at fraud. The margin of $2 \mathrm{lbs}$. may be equally claimed when the horse is registered.to carry extra weight.

In running the best of heats, declarations of changing gentlemen riders for jockeys carrying their specified extra weight, or vice versâ, or any other alterations of surplus weights may be legally made thirty minutes before the time of starting, by public notice affixed.

If a difference of opinion exists before the race respecting the weight to be carried, the owner may secure himself by declaring to carry the top weight, if the stewards are absent, or are incompetent to decide.

Rule 40 is not applicable to matches.

Rule 51.-A merciful alteration has been made in running heats, that when two horses have each won a heat, they only can start again.

Rule 56 is evaded by a very disreputable system of selling by auction, and thereby depriving the owner of the second horse of his legal claim.

Rule 66.-There are three varieties of complaints which must be made within three distinct periods of time. 
1st. Complaints of foul riding, of horses not running the proper course, or of any other irregularities occurring in the race: these objections must be made within fifteen minutes.

2nd. Objections to the qualifications of the horse or of the rider, or of incorrect entrance, must be brought before the authorities before the meeting terminates.

3rd. In the event of fraudulent entry or nomination, running under a false description, the charge may be investigated within the year: all these alterations have been made since 1852 .

In the minor country race-courses, the clerks of the course advertise, "That in the event of a dispute the decision of the stewards is final." This exposes a wonderful ignorance of the British constitution and of the laws of the land-it is the boast of every man in this country that he can appeal to a Court of Law if he fancies himself aggrieved. I am deeply impressed with the incapability of a Court of Law to decide all racing disputes, after hearing the late Lord Chancellor Campbell instruct the jury, in a very simple case at Cardiff, to ignore the rules of racing. He explained to them that they were the judges of the law and the fact, when it was evident neither the judge, counsel, or jury comprehended 
the point at issue. There are some cases of horses running under a false description, or of incorrect pedigree in which there may be a counter swearing, when it is very politic to appeal to a Court of Law, to have the benefit of legal acuteness to elicit the truth-for instance, Running Rein's trial in 1844; but the verdict in St. Giles's trial Derby, 1832, was in violation of racing lawhe was entered with an incorrect pedigree-technical objections are better disposed of by racing men; like disputes at whist or billiards, eminent players or billiard markers form a better tribunal than the whole bench of judges. The Jockey Club, although considered by orthodox sportsmen as the final court of appeal, never dream of attempting to deprive any man of his lawful rights to refer his grievance to a legal tribunalwe bow to the supremacy of the law. 
ON STARTING-RIDING RACES-JOCKEYS.

THE bete noire of racing is the unsatisfactory system of starting, and the helplessness of the official starter to control the audacity of the young jockeys, who frequently set him at defiance. Many persons ascribe the failures to the numerous short races. But some of the worst starts on record are of the Derby and St. Leger. In the olden time, when the Baker started the horses at Epsom, it was considered a good business if they got off within the hour.

The late Lord G. Bentinck put an end to these follies. Invested with full power to fine and suspend, he had no difficulty in starting a large field for a half-mile race. He laid down a rule that the evidence of the jockey was not to be listened to, and the statement of the starter not to be contradicted. The theory was unconstitutional, but in practice it worked well; his success was perfect; the present situation of racing affairs differs widely 
from that of 1845. The number of races, and the fields of horses have increased 30 per cent. During

Houghton Meeting we average ten races per diem, an hour's delay of wheeling into line brings

$\mathrm{s}$ into the dark before we can accomplish our programme; so much therefore the greater necessity for stern discipline and speedy justice.

In 1862 it was proposed to alter the 42nd Rule, imposing fines for the three first offences, and to substitute a suspension, according to the degree of the offence; every man connected with the Turf being aware that the fines were seldom paid by the jockeys, they were added to the training bills. Many horse-owners, standing to win a large stake, would be happy to pay 25l. as a fair investment for an advantageous start: the proposal was not agreed to; and the following spring the starting was worse than ever. Therefore in 1863 the Jockey Club unanimously passed the clause which they had previously negatived. Suspension is our only remedy, we have very few complaints under the management of Mr. McGeorge, except occasionally at the end of the Houghton Meeting, because suspension at the end of the season is not so onerous.

Nothing can be more disorderly than the system of starting on the provincial race-courses. The 
starters are respectable men, but notoriously incapable. They have no control over the jockeys and the public are sometimes induced to believe that the starter has a pecuniary interest in some particular horse; or that he is determined to serve in every instance one particular jockey. When the jockeys behave ill, it is owing to their masters' instructing them to get well off. Country stewards will not efficiently support the starter by fining and suspending; then there is a scene of disorder. We require a person of experience, whose authority must be well supported by the stewards, who will start his horses on a well-defined system, clearly understood by the jockeys. This person must be universally employed, for different systems produce confusion. Newmarket and the principal racecourses could afford to give him 600l. per annum, and money well laid out. No person fills a more arduous or trustworthy situation, if he performs his duty strictly and conscientiously. He may be at variance with the eager jockeys, and occasionally in bad odour with horse-owners, annoyed by the suspension of their hired servants, to whose artless narratives they lend a willing ear.

On the subject of riding races, I have little to add to my remarks in 1852. A good judge of pace, a fine hand, patience, good temper, and high 
On Starting-Riding Races-Jockeys.

courage are the requisites of a jockey. Short races are detrimental to young riders; it encourages them to fight for the start, and to ride like chimney-sweeps on donkeys. I have never seen worse riding than amongst the young crack jockeys this autumn. Three great races were thrown away by a celebrated young jockey, because he could not wait; and he would flog his horse. These boys forget to keep a reserve; if you order them to wait till the last moment, up they go 100 yards from home, take the lead, and the patient jockey hunts him down and wins by a head. Thousands of races are won by a judicious pull, and hundreds are lost by the abuse of whip and spur.

"Parce puer stimulis, et fortius utere loris."

These are the most ancient and the best orders on record. In riding a long race on a horse of superior speed, study the clever instinct of the lurcher in running down a hare: he never distresses himself by over-exertion; he always keeps a pull in hand when the hare is about to turn, he stays away to command the enemy; his tact is to drive him to the fence and pounce upon him at the moment he dwells to clear the well-known gap. Although in the open country, the dog feels his advantage; he will not rush in to kill, because he 
may miss, and throw away a chance, but he will work his way to the old spot, and win on the post. If this instinct can be instilled into the minds of young jockeys, they would sit glued to their horses, and make their effort when within call. I finish this chapter with the remarks I made in 1852. It is extraordinary that we constantly remark lads who as children have ridden feather-weights with great judgment, lose the art as they increase in years. This is owing to vanity, to that rock upon which men of all professions are wrecked, when they flatter themselves they are very clever and have arrived at the top of the tree when they have only reached the lower branches. The result is, they cease to listen to good advice; they ride according to their own fancy, and the first indication of their worthlessness is rolling about on their saddles, and flourishing their whips, instead of sitting still and keeping their horses fast by the head.

In no department of life is the axiom more clearly demonstrated that "Honesty is the best policy," when talent is allied to strict honour and integrity, it is a sure road to comparative wealth; on the other hand, men possessing first-rate abilities cease to prosper from the moment a taint is cast upon their reputation, and their decline of life is invariably marked by poverty and neglect. 
On Starting-Riding Races-Jockeys.

A resolution was passed in 1865 , "That it is desirable that the ancient custom of jockeys having first, second, and third masters, should not be discontinued, and that a jockey should be required to fulfil his engagement when called upon by his original masters according to their respective claims of priority.".

No doubt such a resolution is desirable, but if masters can discharge their servants at the end of every season, the jockeys can withdraw their services at the same period, otherwise the bargain is not reciprocal, consequently illegal.

The regularly established fees for jockeys are 5l. 5 s. for a winning, and $3 l$. $3 s$. for a losing ride; 2l. 2 s. for riding a private trial. If a jockey be ordered to attend a race-meeting, he may charge his expenses to his employer, or divide them between his masters.

A custom has been introduced to charge 257. for riding in the Derby, Oaks, and St. Leger, which the Jockey Club do not sanction. 


\section{CHAPTER V.}

ON THE RULES OF BETTING.

RULE 1. - In all bets there must be a possibility to win when the bet is made.

Remark.-If money be betted P.P. against horses dead or legally struck out at the time the bet was laid, it would be void; but not so if the horse was dying, or if laid before the declaration was made; or if by any possibility at the time the bet was made the horse could start, it would hold good. With respect to bets on facts, if A., after measuring the height of a room, backs his opinion against $\mathrm{B}$., who has never ascertained it, and is ignorant that $\mathrm{A}$. has taken this advantage, the bet would be void; equally so if $A$., after consulting a dictionary, betted on the spelling of a word, the wager would not hold good, because these are attempts to commit robberies.

Rule 2.-The interests of the bets are inseparable with the interests of the stakes, except when the winning horse is disqualified, owing to a de- 
fault in making stakes, or if an objection be made to the qualification of a horse on the ground of incorrect pedigree or nomination after the race is run, the bets shall go to the horse that comes in first, provided he is of the right age, and that in other respects he has not transgressed the 'Rules of Racing;' but if the owner of a horse or a person on his behalf succeeds by fraud or by false statements in starting him for a race for which he is legally disqualified, making himself liable to the penalties in Rule 17, 'Laws of Racing,' the bets will go with the stakes, whether any objection be made either before, or after, the race.

Remark.-If in a match or sweepstakes, the money is not paid to the stakeholder, the horse which wins cannot receive the stakes or match money. The owner must pay the whole amount as a beaten horse, but he would be entitled to receive the bets. This is generally understood. I cannot deny that by artifice a horse owner may gain an advantage by the working of this clause. If, for instance, A. takes 10,000l. to $100 l$. his horse wins the Cesarewitch, and 10,000l. to $100 l$. he wins the Cambridgeshire; by omitting to pay his stake in the former race, he would receive the bet if his horse came in first, but the second horse in the race would be the winner of the Cesarewitch Stakes, and A's. horse would start for the Cam- 
bridgeshire without the $7 \mathrm{lbs}$. penalty. The fraud might be punished by expulsion from Newmarket. I put a hypothetical case, which may never occur, to show the impossibility of any law to debar roguery if the horse owner is so inclined. In order to promote fair play, it is imperative that after the numbers have been Telegraphed under official authority, that objections should be made before the race to protect the public, in default of which the bets go to the horse which comes in first, even if the nominator is subsequently ascertained to be dead, or if the legality of the scratching be disputed without fraud or culpable misrepresentation.

In cases of incorrect nomination-for instance, entering a horse which has won for a Maiden Plate.

$2 n d$. In the case of Newcastle named for the Stakes, at York, 1859, for horses which had never won $100 i$, he having previously won a larger sum; or, 3rd, Starlight winning a 50l. Sweepstakes for horses not engaged in the Newmarket Stakes, in which he was nominated.

4th. Horses in the forfeit list thereby disqualified to run in public being ignorantly allowed to be entered; but if the owner of the horse was aware that his horse was on the registry, it becomes a fraudulent entry, and may be investigated within one year from the date of the offence; bets and stakes would then go to the second horse. 
5th. A horse named for an engagement bona fide the property of officers or of members of a particular club, which on investigation turns out to belong to a stranger. In these cases, if the objection be not made until after the race, the bets go to the horses which come in first, if they are not otherwise disqualified by the 'Laws of Racing,' and if no especial fraud has been perpetrated in obtaining permission to start, but the stakes or plate go to the second horse.

The object of this Rule is transparent. It is presumed that the owners or trainers of the horses engaged ought to have known that No. 1 was not is maiden, that No. 2 had won 100l, which was registered in the 'Racing Calendar', that No. 3 was named in the Newmarket Stakes, that No. 4 was registered a defaulter, and that No. 5 was entered under suspicious circumstances. Then of course the proper time to complain was before the race, when these horses would not have been allowed to start, instead of waiting with a nest egg to ascertain the result of the race, which if farourable to the possessor of the secret would not be mentioned, but reserved for a future occasion. The authorities will not countenance this cunning and duplicity.

Pule 3.-All double bets must be considereã 
Play or Pay. If the first event terminates in a dead heat, and the stakes or plate are equally divided, or if a match be off on equal terms, the bet is off, and the contract is at an end without reference to the future events, which were contingent. Although P. P. betting is a formidable medium to extract money from the public, it must be acknowledged that it is impossible to make a book on any important race without the security of Play or Pay. Strenuous exertions have been made by the Jockey Club since 180t, first to confine the P.P. betting to the Derby, Oaks, and St. Leger, Newmarket Stakes, Oatlands, and the Pavilion Stakes at Brighton; then in 1811 to contract the betting to the Derby, Oaks, and St. Leger. In 1812 a circumstance occurred at Newmarket which ought to have opened the eyes of the Jockey Club to the fact that non P. P. betting was impracticable in large betting races, and that the ring could not protect themselves against the tricks of horse owners without P. P. Two horses belonging to a noble lord-Cwrw, and a colt by Remembrancer - were in the Two Thousand Guineas Stakes. The latter was backed to win 20,000l. He was ridden past the Ring, with Chiffney on his back, and a stable lad on Cwrw. At the starting post, Chiffney changed his mount. 


\section{On the Rules of Betting.}

Civrw became first favourite, and won an immense stake. The Remembrancer colt did not start, by which the Ring lost a great portion of their field money, the Two Thousand Guineas Stakes at that time not being a P.P. race, but it has been so ever since.

The Jockey Club, not enlightened by experience, resolved, on June 1, 1815, "that no bet which shall be made on the Derby and Oaks after that date shall be considered P. P., unless specified as such between the parties at the time the bet is laid. That the above regulation be applicable to the St. Leger Stakes, at Doncaster, from October 1, 1815." This resolution was a nullity, as no bettor would lay long odds without P. P. The Jockey Club stood convicted of imbecility.

It must be evident to every man who will take the trouble to think, that if the Jockey Club had the power to abolish P. P. betting, they could not prevent horse owners from robbing the Ring or their own friends, by starting horses unprepared -if a person has backed a horse for a large sum of money not P. P., there is no satisfaction in seeing him run either lame or coughing, or with a big belly. Make the law as you please, the Jockey Club lave no power to prevent a robbery being committed, if the horse owner, or trainer, or jockey

D 2 
are so inclined; but the present members are infinitely wiser than the preceding generation, they repudiate and ignore betting altogether, and thereby escape the trouble and responsibility of adjudging unpleasant disputes, which fall to the lot of a few men who will work for the public.

There are three modes of betting on single events-Play or Pay, with a forfeit attached, and not P. P. : a P. P. bet, in the event of a compromise. pays and receives in that proportion.

Betting with a forfeit, you may declare to pay. according to Rule 12; having declared forfeit, you receive nothing in the event of the horse you backed winning the race, but you save your forfeit ; in betting on double events, the horse which receives forfeit, or a compromise, on the stakes or match is the winner-" All bets on a match which terminates in a dead heat are void, and if the match be run over again instanter, it is considered a fresh engagement.

If two or more horses run a dead heat in a sweepstakes or plate, and the owners agree to compromise, the bets would be put together and divided in the same proportion as the principals share the prize. There was an old rule which is now acted upon-"All forfeits or money paid on compromising a match or sweepstakes shall bonâ 
fide be entered in the day book, in order that all bettors may ascertain in what proportion they are to pay and receive."

In order to promote sport, and to prevent stakes and plates from being compromised after dead heats, the horses are penalized in all future events to carry any extra weight which the winner of the whole stake would be entitled to carry. In double events, the death of the nominator of a horse named in the contract would nullify the bet; but not so in the event of the horse dying. The reason is obvious, the owner of a lame horse would destroy him to wipe off a bad bet; it would be a different affair to destroy the nominator. If $\mathrm{A}$. takes $100 l$. to $10 l$. that the winner of the Two Thousand Guinea Stakes wins the Derby, and the horse named wins the first event, but is not entered for the latter race, the bet is lost. A. has had a chance to win. If $\mathrm{A}$. had taken a different view of the subject, the explanation ought to have been offered when he made the bet. In this instance, the layer of the odds is entitled to a double chance. In cullateral betting, backing horses to win against losing, the oldest registered precedent, is Case 5 -Sir F. Standish's Royalist, for his two matches. He won the first, and the second was off by consent. The stewards of the Jockey Club awarded 
him one half of the bet. If therefore A. backs himself to win three matches against losing them, and the result is that he wins two, and runs a dead heat or compromises the third on even terms, A. would be entitled to receive two-thirds of the amount of the bet. If in collateral betting, the words "absolutely wins" are used, then all the events must be won iby the same party or the bet is void. If upon backing a certain number of horses against the field, one or more of the horses named should be disqualified, or should have been struck out, or should not have been entered, the bet stands good, provided there be one horse in the lot qualified to run at the time the bet was made; but if all the horses named in the bet were disqualified when the bet was laid, it is void, on the principle that you cannot lose when you cannot win. Bets made when the horses are running are not binding until both parties say "done;" that is to say, that the proposer of the bet responds in the affirmative to the acceptor. If, during the race, a bet is made that a horse actually wins, and he runs a dead heat, the bet is lost. In 1839, when Charles XII. and Euclid ran a dead heat for the St. Leger, heavy bets were made after they had past the winning-post, before the judge's decision was known. A question arose whether 
these bets, according to law, should stand over to be decided by the next heat, or whether they were off. It was determined they should be roid, on the plea that the wagers related to the decision of the judge after the race terminated. With respect to bets made in running, they would be decided by the final result.

If a match be run by mistake, after the principals have compromised, it does not affect the betting on the result. At Epsom, 1796, Lord Clermont's Hornpipe beat Lord Egremont's Atropa, Derby course, $50 \mathrm{gs}$. This match was agreed to be compromised by Lord Egremont paying $35 \mathrm{gss}$; but the fillies had started, and run 200 or 300 yards before the jockeys were informed that the match was off. Atropa's rider then pulled up, but having started it was considered a race, and the bets were paid accordingly. Therefore, whatever agreement may be made to withdraw a horse in a plate, match, or sweepstakes, and the agent is not in time to recall him before the actual start, or before the starter has called upon the rider to take his place, all bets relating to him are Play or Pay. In 1847 , the stewards decided at Newmarket that the winner of a private handicapsweepstakes was exempted from carrying the extra penalty of weight attached to the winners of 
handicaps subsequent to the publication of the weights. This decision was erroneous, and sanctioned neither by law or custom. Fortunately this exemption has never since been claimed; it ought not to be allowed, unless the articles specifies that private handicap sweepstakes have an immunity. It is easy to draw up the articles with this explanation, "Winners of handicaps with public money added, to carry extra."

There is a general antagonism between the patrons and employers of the touters and the owners of horses, who may wish to back them when they think they have a chance to win. In the event of a hopeful trial, the tactics of the watchers are so well established that their information always reaches head-quarters sooner than the report from the stable; and before the owner has made a bet, the cream of the market has been swept off, nothing is left but the skim-milk, or the painful operation of scratching him for his engagement, and incurring the vituperations of the initiated in the garb of injured innocence $w$ ho claim the horse as their private property, on the strength of having backed him, owing to information from their touts, or from some paid traitor in the stable.

Why do you allow that man to ride on New- 
market Heath, when he has owed you money for many yeurs, and you know he is a general defaulter, and that there is not a greater rogue in England? That is the very reason, my friend replied, "I hope he will never be warned off; as long as he is here, he cannot be seen in the ring, but he bets by commission; he is sharp and clever, intimate with all the touts, smells a robbery like a detective, and some day if he escape justice, he will walk into a sum of money, and then I shall be paid. Turn him off the course, and my chance is lost for ever," such is Turf morality-self-interest predominates.

There are three classes of wolves, who prey on the unwary. The welchers, who live by robbery, generally inform their victims that they are members of Tattersall's. 2ndly. The Registered defaulters, who bet outside the ring, some of whom have been warned off. 3rdly. The tolerated defaulters, a large class against whom their creditors will not enforce this law, either from a friendly feeling, or in the hope that eventually the tide will turn, and by patience they may obtain a percentage of their debts. All bets with the first and second class may be declared off, unless the person who wagers with them was aware of their state and condition, then by so doing he puts himself 
on an equality with the defaulters. He has no excuse for not settling in the event of losing his money, although the defaulter cannot appeal for justice, because he is in the situation of an outlaw.

The rule is clear: he who does not pay what he has lost, is not entitled to receive what he may have won, unless he pays his debts within the prescribed time, viz. "one year." It frequently happens, that persons who have neither the means nor the intention of paying their debts, attend at the settling day, collect all the money they can obtain from their dupes, and then levant. In all suspicious cases, every man is justified in withholding the amount of claims if he has good reason to doubt the honesty of the settling. The debtor may refuse to pay, till he is satisfied of the solvensy and good faith of his creditor. It also frequently happens, that persons who have no intention of defrauding their creditors, obtain accommodation for time, or make agreements for future payments. These persons are not to be considered defaulters, and nobody can legally refuse to pay their just claims, if they satisfy the demands of their creditors, in failure of which, any of their debtors may refuse to pay, and the settlement is suspended. A person can only be deemed and treated as a defaulter by 
his absconding or by the sentence of a competent tribunal.

If $\mathrm{A}$. has won money from B., which B. refuses to pay on the plea that A. is in default to C. I)., B., to justify his refusal, must prove that C. D. have demanded their money from A., and have not been able to obtain it, and that it is without their consent that A. remains indebted to them. But I repeat that amicable arrangements between debtors and creditors involving postponements of settlements do not constitute cases of default. If $\mathrm{A}$. has won money from B., and cannot get paid at the proper time of settling, A. may declare off any bets with him on future events. A. cannot declare off his bets with B., because B. is indebted to C. ; but if $\mathrm{A}$. has reasonable grounds for thinking that B. will not pay if he loses, he can protect himself by the 4th rule of betting.

If a person has at any time compromised his betting debts, it is not to be presumed that he will speculate on racing events, until he has paid his creditors in full ; otherwise he can neither in point of justice or good faith exact from any future debtor a larger percentage than he himself paid. The adoption of this principle would give a higher tone to the morality of the betting community, and it ought to be sanctioned by legislative enactment. 


\section{CHAPTER VI.}

ON THE SALE AND PURCHASE OF HORSES.

A Racenonse, if sold without insertion of his engagements, is deemed to be sold without them. If it is intended that a horse shall be sold with his engagements, it should be so expressed before the contract of sale is concluded; and if the horse is sold by public auction, it should be so stated in the catalogue of sale, or announced by the auctioneer when the animal is put up for sale.

As the value of a racehorse frequently depends upon his engagements, it is of the utmost importance to the buyer, that at the time of the sale he should inquire of the seller what engagements the horse is under; and to the seller that he should, upon such inquiry, fully and truly disclose them.

So in like manner should inquiry and disclosure be made of any matters which operate as disqualifications or obstacles to the horses starting for any 
race; such, for instance, as default in payment of former stakes or forfeits (see Rules 26, 27), \&c., \&c.

When the purchaser may return the horse; when he cannot return him, but may sue the seller in an action at law; and when he can do neither, shall shortly be considered; but before doing so it will be well to call attention to the distinctions well recognized by the lawyers, though very imperfectly understood by others, between a warranty and a mere representation-because unless this distinction is appreciated, the respective rights and liabilities of the purchaser and seller can never be rendered intelligible.

First, then, as to a warranty :-

A warranty always forms, and by each of the parties must, at the time of sale, be understood to form, a part of this contract of sale. It is, in short. a statement respecting the horse, coupled with an undertaking or agreement on the part of the seller that such statement is true and correct in every respect.

No particular form of words is necessary to constitute a warranty; nor need a warranty be in writing, It is sufficient if the language used is such that from it, it can fairly and reasonably be inferred that both parties intended that a promise 
on the part of the seller that his statements respecting the horse were true and correct, should form a part of the bargain between them. It need hardly be suggested that for the sake of disputes, whenever a warranty is intended it will be prudent to have it put into writing.

A mere representation, as distinguished from a warranty, forms no part of the contract-it amounts merely to an assertion of that which is represented, with an intimation, expressed or implied, of the seller's BELIEF that what he so asserts is true.

The difference, in short, is between a promise that the statements or representations are true, and a mere expression of belief that they are so.

Those who desire to read a case which has been determined in the Court of Common Pleas, fully illustrating the distinction which has been pointed out, will find such a case in Hopkins v. Tanqueray, 15 Common Bench Reports, 130.

An erroneous statement by the seller touching the horse or his engagements, or any unpaid stakes or forfeits due for him, or even a total omission to mention such engagements or unpaid stakes or forfeits, does not necessarily vitiate the sale and entitle the purchaser to return the horse, 
or to bring an action against the seller. The maxim, caveat emptor is equally applicable to a purchaser of a racehorse as to any other commodity.

To entitle a purchaser to repudiate the sale and return the horse, and demand back the price, he must prove one of two things.

First.-That by the terms of the bargain it was agreed, that in the event of the horse not turning out as represented, or having engagements, or of there being unpaid stakes or forfeits due for him, the purchaser should be at liberty to return him; or in other words, that the sale was conditional upon the horse turning out as represented, and upon his engagements and all unpaid stakes and forfeits being fully disclosed : or,

Secondly. - That he was induced to purchase by the fraudulent misrepresentation or concealment by the seller, or his agent, of matter material to be known by the purchaser, to enable him as a prudent man to make his bargain.

But in order to entitle the purchaser, in any case, to return the horse and recover back his purchase-money, he must repudiate the contract immediately he becomes aware of the circumstances which entitle him to return it; and he must also be in a condition to return the horse in 
the same state and condition ais he was at the time he was received.

For a simple breach of warranty the only remedy is an action for damages; the measure of such damages being the difference between the horse as he really was at the time of the sale, and the value of which he would have been had he been as he was warranted to be; and also such expenses as have been fairly and reasonably incurred by reason of that breach of warranty.

Subject to what has already been stated, a purchaser who has been induced by the fraud of the seller to purchase a horse may either return him and recover back the price, or sue for the dainages which he has sustained.

For a mere representation made without fraud, which turns out to be untrue, the purchaser has no remedy whatever.

As a general rule it may be taken that, in all cases, where there is no writing binding the parties, the question whether there was a warranty or not-or whether there was fraud on the part of the seller, is one of fact to be determined by a jury, if the parties do not agree upon any other tribunal to settle their differences. 


\section{On the Office of Steward.}

It will be well for every gentleman who undertakes the duties of a Steward at a county race meeting to be informed of the liabilities he takes upon himself in accepting that office, and of the rights and privileges conferred upon him by virtue of it.

In law, a Steward is liable in respect of all things done or ordered in his name, by his authority, either expressly or impliedly given; and he cannot shelter himself from that liability by proving that the funds at his disposal are inadequate to the demands upon him, unless, indeed, he can also prove that the persons whose claims are in question agreed to look to the funds alone, and not to the individual responsibility of the Stewards.

A Steward is not bound to make good any deficiency in the stakes advertised to be run for. Nor is he the person to whom the winner can look in law for payment of the stakes won, unless he, or any agent of his, has received the money. The Clerk of the Course usually is the person with whom the stakes are deposited as stakeholder, and he, as such stakeholder, is independently respon- 
sible for all moneys which come to his hands. Those moneys he holds, not as agent or servant to the Stewards, but as an independent official, subject, however, to the judgment of the Stewards whenever disputes arise as to the person who is entitled to receive them as winner.

Of course, the Stewards may, if they please, treat the Clerk of the Course as their mere agent, or appoint any other person as their servant, to receive and hold the stakes in their name; in which case they would be liable for them. But, unless they do so, they are in nowise responsible.

The duty of appointing the Judge and the Starter devolves upon the Stewards, who should take care that those offices are efficiently filled; for there is no appeal against the decision of either Judge or Starter upon those matters which it is their province to decide.

The decision of the Judge is final upon the question of the order in which the horses pass the winning-post, unless, indeed, it can be shown that his decision is corrupt and wilfully at variance with the fact. The decision of the Starter as to the start is equally final.

Appeal, however, may be made to the Stewards upon all other questions. Such, for instance, as questions as to the disqualification of any horse 
objected to, the weight he carried, the mode in which he was ridden by the jockey, \&c.; indeed, any question which involves the right of a horse to be deemed the winner, or to a place in the race, notwithstanding his having first passed the winning-post.

When by the articles it is provided that disputes are to be decided by the Stewards, their decision upon such disputes is final, and cannot be reversed in a court of law,- - even though it may be clearly erroneous,-provided there be no ground for impeaching it on the ground of fraud or corruption of the Stewards themselves.

So long as a dispute remains under the consideration of the Stewards, the stakes cannot be recovered from the stakeholder. This was expressly decided in a case of Brown against Overbury, tried before Mrr. Justice Coleridge, at Warwick Assizes, in 1855, wherein it appeared that, in the spring of that year, a steeplechase was run near Henley. Overbury, the defendant, was treasurer of that race, and Brown, the plaintiff, sought to recover 26l., being the amount of the stakes which he alleged were won by his horse 'Minor.' According to the articles, any dispute as to the race was to be decided by the award of four Stewards. A dispute arose. The Stewards met, 
but were unable to agree as to the winner, two being in favour of 'Minor,' and two in favour of another horse called 'Prince Albert.' The plaintiff proposed to prove to the jury that his horse had won, and contended, if he did so, he was entitled to the stakes; and that even if he failed to do so, he was, at all events, entitled to recover back the amount of his own contribution to the stakes. Mr. Justice Coleridge was of a different opinion, and nonsuited him. On appeal, afterwards made to the Court of Exchequer (11 Meeson \& Welsby, 715), the Court (Barons Alderson, Platt, and Martin) held that Mr. Justice Coleridge was right, and that the plaintiff could not recover the stakes or his own contribution whilst the matter remained, as it was, undetermined by the Stewards.

If there are several Stewards, it is not essential to the validity of their decision that they should be unanimous. If, after discussing the matter in dispute, they differ in opinion, they may treat the decision of the majority as their decision. (Parr $v$. Wintringham, 1 Eilis \& Blackburn, 394.)

It is no objection to the decision of the Stewards that one of them had an interest in the race,e.g. by having betted on or against any other horses in the race. (Ellis $v$. Hopper, 4 Hurlstone \& Norman, 765). 
As a general rule, it may be taken that, during the days of racing, the race-course and inclosures are in the legal possession of the Stewards, and that they have, for all purposes connected with the races, the authority of the owner of the ground to order off every person whose removal they deem desirable.

The purchase of a ticket for the inclosure gives the holder of it no legal right to remain there after he has been warned to depart; and if he refuses to quit, he may be removed with such force (but no more) as is necessary for his removal: see Wood v. Leadbitter, 13 Meeson \& Welsby, 838, which was an action by the plaintiff Wood against Leadbitter, the defendant, for removing him from the inclosure attached to the grand stand at Doncaster. It was proved that Lord Eglinton was Steward of the races there in 1843 ; that the plaintiff had purchased a guinea ticket for the stand and inclosure for the week; and that, while the races were going on, he, being in the inclosure, was ordered by the defendant, who had the authority of Lord Eglinton for that purpose, to depart. He refused to go; whereupon, the defendant, using no unnecessary violence, turned him out without returning the guinea. It was held by the present Lord Chancellor, then Baron 
Rolfe, who tried the cause, and afterwards by the full Court of Exchequer, that the right conferred by the ticket was a mere licence to remain in the inclosure until it was revoked. That Lord Eglinton had the power to revoke it at any moment; that having done so, the plaintiff's right to remain in the inclosure was at an end; and that, as he had refused to depart, he was legally ejected.

The grounds upon which that decision was arrived at it is not necessary, nor would it be useful, in this work to discuss. It is sufficient to say that so was the law laid down, and so it is.

\section{The Clerk of the Course.}

In drawing up the articles of the racing programme, avoid the modern extortions from the owners of horses; sales by auction, unless the second horse receives half the profit; plates, the winner to pay back a percentage, which is giving with the right hand and stealing with the left.

Do not tax the stable-keepers and the blacksmiths to encourage them to make horse-owners pay double. Some country programmes state that horses will be disqualified to win if they come in first, unless they stand at the stable of a subscriber, and are plated by a subscribing black- 
smith; this is abrutum fulmen. It would be difficult to find a gentleman steward so void of sense as to countenance this outrage, which sets racing and national law at defiance. Omit that encouragement to vice, "Horses that have started twice without winning allowed $5 \mathrm{lbs}$, three times or more 9 lbs." This is the excuse for running horses out of condition to get them beaten, and to reap the reward of false play; instead of stating in your programme, "All winners of handicaps to carry extra penalties after the weights appear," say, "Winners of handicaps with public money added," because this will not affect private handicap sweepstakes. Never publish your handicaps during the racing season one day before there is a necessityevery day's running throws a light on the subject; but the sooner you bring out the spring handicaps, which close in January, the larger will be the acceptance, because the owners are flattering themselves that their screws will stand another preparation, and they do not discover before March that the hard work and ill-treatment of the twoyear-olds has brought their racing form to a standstill, and that they have not made the natural improvement since the autumn.

In all sweepstakes closing on a certain day, which may fail for the want of a stated number 
of subscribers, if the said sweepstakes be reopened, none of the names of the original subscribers can be left in without their renewed consent; and after the terms of a sweepstakes have been published and nominations made, the engagements would become void by any alteration of weights, distance, or of the day fixed, without the concurrence of every subscriber.

Before a sweepstakes closes, a subscriber may change a horse already named, but this rule does not hold good in naming for a plate; a nomination for a plate pays entrance money; you cannot withdraw it, but you may add any number of horses. A horse cannot be entered for any stake or plate after the specified time has elapsed, without a general consent of the subscribers.

When the Clerk of the Course sends a public return of the races to the official register, he should name the exact weight every horse carried.

\section{The Judge}

Should receive the list of the horses weighed from the Clerk of the Scales, with the colours of the riders. He should not allow any person or moving object to touch the opposite winning post. When the heat is over, he should write down the colour 
of the winning jockey, and the second and third; then telegraph the corresponding number; in default of a telegraph he must proclaim the winner.

The decision of the judge is final.

If the judge's chair be vacant, or if no person officially appointed occupies the chair when the running horses pass the winning post, the heat is void, and must be run again instanter.

In running the best of heats, a horse cannot be distanced unless a person is stationed at the distance post with a flag to signalize to the judge when the last horse passes that post.

\section{The Starter}

Should be allowed an assistant, who should be stationed about 100 yards in advance with a flag. If the assistant-starter drops his flag in response to the signal from his chief, the starter cannot again elevate his flag or call back the horses; it must be considered a legal start; but as long as the starter's assistant keeps his flag elevated, no start can legally take place. If there shall be a large feld of horses, or any anticipated difficulty in getting them well off, the starter should form his line 100 yards behind the starting post and walk 
them up, which is the only plan to facilitate a fair start. To start horses from the wrong side of the post nullifies the race, and imposes a fine of $50 l$. on the starter.

If any jockey attempts to take an unfair advantage, or if a jockey purposely stays behind, or pulls up after the horses are off, it is the duty of the starter to note the same in his book and report it to the stewards.

If, owing to unforeseen delays, the jockeys are prevented from arriving at the starting post at the hour named, the starter should report it, and ask for an extension of time from the stewards, otherwise the starter has a heavy responsibility, because he is ordered to start the horses at a fixed minute; he has a discretionary power to wait for a horse if he sees him coming. When a horse bolts and runs away off the course, the stewards should determine whether the starter should keep the horses waiting for him. If the horses run the course, and the stewards decide it is a false start, they must return to the post without delay; no other race can legally intervene. If a dispute arises between the jockeys for choice of ground in a match, it must be decided by toss; if between jockeys in a sweepstakes, by drawing lots.

The decision of the starter is final, unless his 
testimony is contradicted by his assistant; and his charges against any jockey for foul play, or of attempting to take an unfair advantage, must be attended to. If his authority is not well supported by the stewards, there is an end to fair racing.

\section{On the MLanagenent of a Stud.}

The best site for a breeding establishment is undulating ground, on a light soil, over limestone, then over chalk, gravel, sand, and loam welldrained; and the worst selection is a rich wet pasture, on stiff clay, which is only fit for cattle and cart-horses.

In laying down the paddocks, if you have an extensive command of ground, divide them into parallelograms of about four acres, with a central building in four compartments, each compartment opening into a straw yard about $30 \mathrm{ft}$. by $20 \mathrm{ft}$., with a high paling, and a door from each strawyard to their respective paddocks; this central building saves a great deal of labour in supplying the stock with food and water, and diminishes the expense of building. A single hovel, capable of accommodating two yearlings or a mare and foal, cannot be efficiently constructed under $75 l_{\text {; }}$; but the four-room dwelling, with a straw loft above, may be built for $200 l$. The lower positions should 
be $14 \mathrm{ft}$. in height, with a large window ard a ventilating chimney in the centre, and a pump of good water in the vicinity. The fences of the paddocks should be blackthorn, guarded by rails or by wooden paling, which is preferable to stone or brick walls. The land cannot be too well drained, and the coarse grass should be fed down during the winter by lean cattle.

With respect to brood mares, whatever may be the object in view-race-horses, hunters, or hacks - there are some points never to be overlooked, great width over the hips, deep slanting shoulders, short clean legs, with large knees, sound feet, and well-defined houghs. Mares which have never carried a saddle are preferable to those which have been trained or hard ridden, unless they have distinguished themselves by their performances. If barren mares are used in light work, carting hay and straw, they would be more likely to breed than if they lived in idleness. When a mare drops a foal, she ought to be fed with mashes of bran and bruised oats, to keep her bowels in a laxative state. She will be ready to take the horse on the eighth or ninth day, and the best reason for indulging her without further delay, is because she is likely to conceive on her first pride, and when she is in use her milk purges the foal. 
Thorley's patent food has frequently the same effect on the milk; there is no better food than carrots.

The groom should ingratiate himself with the foal as early as possible, constantly handling him until he can lift up his legs and tap the feet, first with his hand, then with a stone; because when a foal is three months old, owing to standing either on grass or a straw bed, his feet require to be rounded at the toes and the heels kept open, and this process ought to be attended to every month.

If the foal runs wild for four or five months, it often becomes a dangerous struggle between him and the blacksmith the first time he is pinned up to attend to his feet, and many foals have been seriously injured during the operation. When a foal is weaned, he will fall away in condition unless he has Thorley's food in addition to his mashes of bran and bruised oats, or steamed barley; after he is reconciled to the maternal loss, give him oil to ascertain if he has worms, the best cure for which is ipecacuanha in a mash of bran, after twelve hours' abstinence from food.

When the yearlings are taken up and are inured to discipline, gire them three gentle doses of physic at intervals of a month or six weeks, and 
five or six hot-air baths. Never be in a hurry to back a colt if he is naturally impetuous.

The education of a colt should be like that of a child: he should be talked to and treated with kindness and firmness, and never be allowed to play tricks. Abdel Kader says: "Remonstrate with your horses, and they will avoid the faults which have brought down your anger upon them, for they understand the wrath of man; treat them habitually with great gentleness, and when you mount them, fear not to guide them into the midst of a crowd or of uproar. Let them see everything which appears strange to them, and in a short time they will manifest neither surprise nor terror."

The extravagant prices which good-looking yearlings command in the market, have given a great impetus to the breeding establishments, the majority of which enjoy wholesome profits; but, with the exception of the owner of Middle Park, I cannot discover amongst the gentlemen who breed racehorses for sale, one person who is willing to contribute the slightest percentage of his gains to form a fund for a great national prize, although the value of their stock will be enhanced in proportion to the amount of prizes in prospectu; the extent of their patriotism in a national point of 
view, to improve the breed of horses, appears to be in a corresponding ratio with the amount of their annual sales.

There is no greater folly than to shut up mares or horses of any description in hovels or stables imperfectly ventilated. The windows of a stable ought never to be shut by night or day; in cold weather add to the clothing, but never deprive them of the first great source of vitality, "fresh air."

When a horse in training or in hack-exercise bites his clothes, strip him: he is a better judge of what is beneficial to himself than the cleverest groom. Light-fleshed horses and mares ought never to be exercised in warm clothes. Thicknecked gross horses, with strong constitutions, require artificial aid to reduce their flesh, which can only be done by hoods and extra blankets. Generally speaking racehorses ought to be galloped stripped all the year round, but comfortably clothed in-doors suitable to the temperature.

I have no doubt that roarers might be improved a stone, if they were trained from an open shed, sheltered from wet and rain, keeping them warmly clothed and always in the open air.

Stallions should never be shut up, they require no clothing excepting during a very severe winter. 
They should be ridden or led about for two or three hours every day. The confinement of a stallion in a close hovel, without exercise, makes him susceptible of disease, produces fever in the feet, and diminishes his power of procreation. Thirty mares is a full allowance for any stallion; the number of weedy animals we see in training is owing to the stallions being worked beyond their natural powers of healthy vigour.

In all our great horse-breeding establishments for public sales, the ground is too limited, and the paddocks are tainted by the number of occupants.

In Count de la Grange's stud in France, I am informed that the yearlings are never shut up, but are allowed a very extensive range of pasture; this is the true policy; it stands to reason, they have an enormous advantage over our stall-fed stock, but as long as the yearlings fetch fancy prices there will be no reformation or improvement ; it is a case of pounds, shillings, and pence. We lose every year our crack stallions, because the wise government in France will buy the best articles, and there is no public fund in this country to act on the defensive; everything here depends upon private individual speculation. 


\section{Racing Cases.}

\section{Racing Cases.}

1.-Cases of Three Year Olds Running for Four Year Old Stakes, foc.

The King's Plate at Lewes, 1769, for six year old horses, 12st. four-mile heats, was won by Mr. Wildman's ch h Eclipse, 5 yrs. beating Kingston, 6 yrs.

The Duke of Rutland's Bonny Black, 4 yrs., won the Cup at Black Hambleton for five year old mares.

October, 1826, one-third subscription 25l., for five year olds, to carry 8 st. 81 b. ; six, 9st. ; and aged, 9st. 3lb. Lord Wharncliffe's El Dorado, 5 yrs. beat Lord Egremont's gr c Stumps, 4 yrs.

Bedford Races, 1849.-Mr. Edward's Bedford, 3 yrs., won the Hunter's Stakes, carrying four year old weight.

\section{2.-Jockey Changed in the Race.}

Melton Mowbray, August, 1728.-A Plate of 20l. ; 10st. each. Two miles. Winner to be sold for $40 \mathrm{gs}$.

Isord Essex's Bay Motte . . 2 ' 11 Mr. Bertie's White Stockings $12 \mathrm{dr}$. 
In the first heat both jockeys fell, and the rider of Bay Motte was so much hurt that he was unable to mount again; but Lord Essex's groom being near, immediately mounted the horse and saved his distance.

This is the first instance on record of a change of jockeys in running.

3.-Both Jocksys Falling Abreast Winning-post.

Oxford, August 22nd, 1732.-A Purse of 20 gs., for any horse that never won 40 gs. ; 10 st. each ; heats.

Mr. Hornsby's gr h John Trot. $\begin{array}{lllll}3 & 1 & 2 & 1\end{array}$ Mr. Fry's b g Conqueror ․ . $0 \begin{array}{llll}0 & 2 & 1 & 2\end{array}$ Mr. Harvey's br h Merry Tom. $0 \begin{array}{llll}0 & 3 & 3 & 3\end{array}$

In running the third heat Conqueror and John Trot fell just at or very near the ending-post, which gave rise to a question whether either of them had supported his weight past the post, or whether the heat should be given to Merry Tom.

The dispute was decided in farour of John Trot, upon a person's making an affidavit that before he fell his weight at least had passed the endingpost. 


\section{4.-Mr. Sparrow's Badger.}

Reading 50l. Plate, 4 miles. 1753.

Mr. Sparrow's Badger not arriving in time for the first heat, the stewards agreed that he should start for the second heat if he performed the distance by himself in 9 min. 20 sec., which was the time Poor Robin, 10 st. $5 \mathrm{lb}$., ran the first heat in; but Badger not performing the 4 miles under 10 min., was deemed distanced.

\section{5.-Both Horses Thrown-Singular Judgment.}

\section{Chelmaford Races, 1797.}

On the Thursday, Sir C. Bunbury's Cedar and Mr. Perren's Peeping Tom started for the Maiden Plate, heats. Not far from the ending-post, both horses were thrown down by a servant employed to clear the course riding across them. Peeping 'Tom died soon afterwards. Cedar was brought round and carried in his weight, but did not go round for a second heat.

It being objected that Cedar was not entitled to the plate, not having won a second heat, the matter was referred to a committee of the Jockey Club, who determined that Peeping Tom being distanced the first heat, it was not necessary for 
Cedar to go round for a second heat; and that, therefore, he was entitled to the plate.

The stewards of the Jockey Club disapproved of this decision, and formally protested against it in a memorandum signed by Mr. Lamb and Mr.Wilson.

In order to sanction this decision made by the Committee, Sir C. Bunbury introduced the following rule :-

1798. "If a horse wins this first heat, and all others draw, they are not distanced if he starts no more; but if he starts again by himself, the drawn horses are distanced."

In 1803, being ashamed of their proceedings, the Jockey Club expunged this order, and virtually condemned the decision which the general meeting of the Jockey Club had confirmed.

\section{6.-Distinction between a Plate and Sweepstakes.}

At Carlisle, in 1798, a Maiden Plate was given by the Earl of Carlisle for any horse, mare, \&c., that never won the value of 507., matches and sweepstakes excepted.

Little Scot won it at two heats; but it was proved, and the objection was made before starting, that he had won a plate of 50l.; but it appeared to be a sweepstake of $10 l$. each, with $50 l$. added by the Corporation of Richmond. 
The stewards of the Jockey Club decided that " the prize run for at Richmond must be considered a sweepstakes, inasmuch as the horses were named sereral months before starting, and instead of any entrance being paid, a stake of $10 l$. was to be made; Little Scot is therefore entitled to the plate."

7.-Difference between Nomination of a Hunter's Stakes and a Thorough-bred Racing Stakes.

For the Hunter's Stakes at the Chesterfield Meeting, 1798, A named b g Duncan, 6 yrs.; B named a b $\mathrm{m}$ by King Fergus, dam by Highflyer, 6 yrs. B complains that A has not sufficiently identified a horse, and therefore has not a right to start.

The stewards of the Jockey Club decided that "the nomination of $A$ 's gelding by the name of Duncan is sufficient, and justified by constant usage."

The same case was stated from Lichfield, and the same answer given.

Signed per order (1798), ED. Weatherby.

For the Two Thousand Guineas Stakes, in 1828, Mr. Mr. French named a colt as Palemon, without any further description. An objection was made, and the case referred to the stewards, who decided he could not start.

Remark.-The former case was a half-bred 
horse running for half-bred stakes. Horses not thorough-bred have no pedigree.

\section{8.-Whether a Horse Winning a Sweepstakes} Tuenty-three Guineas each, Three Subscribers, could Run for a Plate for Horses which never won Fifty Pounds.

Whether a horse having won a sweepstakes of 23l. each, three subscribers, is qualified to run for a 50l. plate, expressed to be for horses that never won plate, match, or sweepstakes of that value.

It was decided that it was the practice in estimating winnings to consider the clear sum gained only, and consequently to exempt the stake of the proprietor; the horse, therefore, which had won a sweepstakes of $46 \mathrm{gs}$. only-viz. two stakes of $23 \mathrm{gs}$. each, was not thereby disqualified for the 50l. plate above mentioned.

\section{9.-Distance Measured after the Race found Short.}

$A$ betted $B$ that a mare should trot a mile in five minutes, in four minutes and a-half, and in four minutes-all which it was stated she won with ease; but $\mathrm{B}$ measuring the distance after the race was over, found it was short of a mile by four yards.

It was decided that as no objection was made to the measure of the course before starting, and 
the mare having performed the distance set out and not objected to, A won all the bets.

10.-Whether a Compromise was Forfeited by the Horse Omitting to Walk Over.

Lord Grosvenor's Rosamond and Mr. Foley's Mistake were matched on the Tuesday for 200, h ft. On Monday Lord Grosvenor agreed with Mr. Fox on the part of Mr. Foley to pay the forfeit of the match on certain conditions, to which Mr. Fox agreed, and accepted the forfeit. Mistake did not walk over the course for the forfeit of the match on Tuesday.

Query.-Is Lord Grosvenor obliged to pay the forfeit?

Referred to the Duke of Grafton, Lord Bolingbroke, and Sir C. Bunbury, stewards; with the Duke of Ancaster, named by Lord Grosvenor, and Lord Farnham, by Mr. Fox, for their decision; who were of opinion that the agreement between Lord Grosvenor and Mr. Fox, made on the Monday, ought to stand.

11.-Whether the Winner Distancing the Field is Entitled to Second Money.

[The original adjudged case answering to No. 2, 'Racing Calendar']-Articles: "The stakes to 
go to the second-best horse that wins a clear heat."

For this plate Medley won the first heat; Smart won the second heat, distancing Medley (who fell) and all the other horses; and Smart walked over for the third heat. The owner of Smart claimed the stakes as well as the plate. The owner of Nedley claimed the stakes.

The stewards of the Jockey Club decided that Smart, being the winner, cannot be deemed the second-best horse, and therefore is not entitled to the stakes; to which the owners of the other horses being distanced have also no claim.-Newmarket, November 3rd, 1784.

The same decision was given by the stewards of the Jockey Club, when Brownlock walked over for the Blandford Cup, in 1829. As there was no second horse which would have been entitled to the surplus specie, it was divided amongst original subscribers.

12.-A Horse Objected to in a Maiden Plate for previously Receiving Second Money.

[The original adjudged case, answering to No. 32, 'Calendar.'] - At Chelmsford, 1789, a Cup and 


\section{Racing Cases.}

Sweepstakes, 10l. each, for horses, \&c., that had never won.

Mr. Godfrey's Judgment . . . 1

Mr. O'Kelley's Hunter . . . . . 2

Mr. Tindall's Prince William . . . 3

The prize was claimed by Mr. O'Kelly, on the ground that Judgment had received stakes for being second in the plate at Chelmsford the preceding year.

"The stewards of the Jockey Club are of opinion that Judgment was not disqualified, and that the term winner applies only to the horse that beats all the rest.

"1789.

"Signed (per order),

"Ed. Weatherby."

13.-Rasselas's Case-Wrong Decision.

Aiter the race for the Somersetshire Stakes at Bath, in 1829, it was discovered that the person in whose name Rasselas was entered was dead before the race was run; and Mr. Day, the owner of Liston, who came in second, claimed the stakes. The matter was referred to the stewards of the Jockey Club.

It was decided that Liston was entitled to the stakes, because, of all the horses qualified to start for the stakes, he was the first, Rasselas being dis- 
qualified by the death of the person in whose name he was entered. But the stewards thought that in this case, as in that of a horse disqualified to start, from the stakes not having been duly made, the bets should stand according as the horses came in.

This decision is at variance with the fundamental principle of racing-viz. that the interests of the stakes and bets are inseparable, excepting where stakes have been omitted to be made; the nominator of Rasselas was known to be dead, and was buried at Bath, therefore Rasselas ought not to have been allowed to start, and the bets as well as the stakes should have been awarded to Liston. "As at that time there was no law that unless the objection was made before starting, the bets should go to the horse which came in first." According to the 16th law of Racing at that time established, repealed in 1739.

14.-A Horse Illegally Allowed to Start for a Fourth Heat.

Holderness Hunt, 1838. - The Scurry Stakes. $\begin{array}{lllllll}\text { Mischief . . . . . } & 0 & 0 & 0 & 1 & 1 \\ \text { Mr. Merryman . . . } & 0 & 0 & \text { l } & 2 & 2\end{array}$

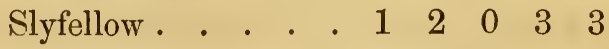
Gangarine . . . 21 dis. 
Gangarine came in first the third heat; but a cross having been proved against him, it was given to Mr. Merryman, who ran second; and as Gangarine had won the second heat and was subsequently disqualified, that heat was considered null and roid; but according to the twelfth rule no other horses but Mr. Merryman and Slyfellow were qualified to start for a fourth heat; and Mischief illegally won the plate.

15.-Two Horses Running Five Miles and a-Half instead of Four Miles, by Mistake.

Ayr Races, 1813.-A Plate of 507. for all ages.

Four-mile heats.

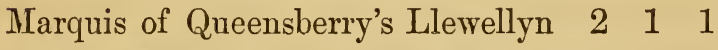
Sir W. Maxwell's 'Tam-o'-Shanter . . 12

By mistake these horses went round the course once oftener than was necessary, the first heat making a distance of about five miles and a-quarter, at the end of which Llewellyn was first; but Tamo'-Shanter having the lead at the end of four miles, the heat was adjudged to him.

\section{6.-Match Starting at the Wrong Post.}

At Lewes Races, 1805, Sancho and Bobtail, by mistake, started at the wrong post, and ran about 
one mile and a-quarter, instead of one mile, for which the race was made. Sancho came in front.

"The stewards of the Jockey Club are of opinion that the race was valid, as they had completed the distance, and Sancho was the winner.

$$
\begin{aligned}
& \text { "Signed (per order), } \\
& \text { "E. Weatherby." }
\end{aligned}
$$

17.-Stewards Revoking their Decision after

Distancing a Horse.

Dumfries, October, 1795.

Lord Darlington's b m Constant. Sir H. Williamson's b h Hamilton.

In the last round of the first heat Hamilton went off the course, and lost so much ground, that from the dropping of the flag at the distance-post, it appeared to the stewards that Hamilton was distanced, and it was declared accordingly; but upon hearing the evidence of the starter, who declared Hamilton had passed before he dropped the flag, the stewards revoked their first decision; and Lord Darlington refusing to start his mare again, on hearing the first decision of the stewards, Sir H. Williamson's horse walked over the course.

The stewards of the Jockey Club decided that the stewards of Dumfries had a right to revoke 
their decision of Hamilton being distanced on the evidence of the person who held the distance-flag, and that the parties concerned, according to the articles advertised, were bound by the decision of the stewards.

18.-Short of Weight-Horse Taken Away--Bridle not Allowed.

Buxton, 1825-A plate of $60 l$.

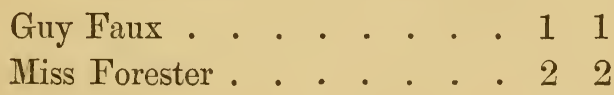
Arachne . . . . . . dis.

Arachne came in first for both heats; but her rider weighing after the first heat without his bridle was a trifle short of weight, and the filly had been incautiously led away. An objection was made, and she was allowed to start for the second heat, under protest, subject to a subsequent decision.

It was adjudged that she was distanced.

An identical case happened at Doncaster, 1809, when the Duke of Hamilton's Petronius having won the third heat of the 100l. plate for three and four year olds, was incautiously led away from the weighing-stand,-the jockey was a trifle short of weight, and the bridle was not allowed to be added. 


\section{9.-False Start-St. Leger.}

Doncaster, 1819.—St. Leger Stakes.

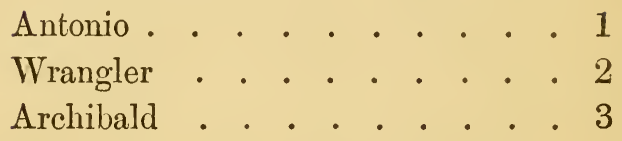

In consequence of a representation to the stewards that several horses at the starting-post had not gone off with the rest, the above was in the first instance declared a false start-subject, however, to a reference; and a fresh race was run as follows :-

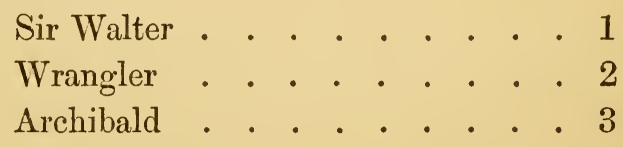

But the whole question was subsequently referred to the stewards of the Jockey Club, who having examined Mr. Lockwood, the person appointed by the stewards at Doncaster to start and judge the race, decided that the race should have been adjudged to Antonio, and consequently that the Doncaster stewards should not have allowed a second race.

$$
\text { Signed (per order), }
$$

October.

E. W. 


\section{0.-Disputed False Start at Newmarket.}

For a race in the Houghton Meeting at Newmarket, 1829, a filly turned round at starting, and was left behind. The start being disputed, the race was run over again, subject to an examination by the stewards into the circumstances of the first start. When this inquiry took place, it was satisfactorily proved that the starter gave the word "Off," and did not call to the riders to come back; it was therefore determined that the first race was decisive. Suffolk Punch won the first race, Aranda won the second.

Remark: The starter should have been examined instanter; for the very circumstances of allowing the horses to run again substantiated the invalidity of the first start, and a part of the evidence was not published-viz. the starter being asked why he did not call the horses back, said he was not in the habit of calling them back, because when one was left behind the others came back of their own occord.

This adjudged case was, at a general meeting of the Jockey Club in 1838, ordered to be omitted in the publication of the 'Racing Calendar,' 1839; and all disputes respecting a false start have been ever since decided solely on the evidence of the starter. 
21.-Jockey Thrown after Passing Winning-post. Beccles, 1826.-Town Plate of 507.

Dumps . . . . . . . . 11 ch c by Abjer . . . . . . . 42

Cocktail . . . . . . . 33 Fleance . . . . . . . 2 dis.

In the second heat Dumps, after passing the winning-post, was thrown down by a man crossing the course; and in the first heat the Abjer colt bolted, and ought to have been distanced.

The owner of Cocktail claimed the plate on the plea that the rider of Dumps dismounted before he came to the weighing chair.

The stewards of the Jockey Club decided that, under the circumstances, Dumps was not thereby disqualified.

22.-Jockey Dropping Stirrup-leather after Passing Winning-post.

A jockey of a winning horse, after passing the winning-post, loses his stirrup-leather and iron, which falls to the ground; it was handed to him by a person on the course before going to the scales to weigh. Query: Does the act of receiving the stirrup-leather and iron, and carrying the same to the scales, disqualify the horse rode by 
that jockey, although it was proved that he was the proper weight without the said, stirrup-leather and iron?

"The stewards of the Jockey Club are of opinion that the horse is not disqualified under the circumstances above stated.

"Signed (per order),

"1837. "C. Weatherby."

Grey colt Mercury, Curragh, September.

23.-In Making Stakes the Trainer considered as the Agent.

West Kent Stakes-Chatham, 1842, the first day; Mr. Dockeray's f Despatch wins a 50l. plate; the second day Mr. Duppa (whose horses are trained by Mr. Dockeray) names Lyster for the West Kent Stakes. No race takes place, but Lyster walks over for the forfeits. Mr. Duppa not having paid his stake for Lyster, it is objected that Lyster is not entitled to receive the forfeits.

Mr. Dockeray contends that as the managers of the races held $50 l$. of his money, viz. the winnings of Despatch, he was entitled to consider that a sufficient payment for Mr. Duppa's stake.

It was decided that as Mr. Dockeray was the trainer of Mr. Duppa's horse Lyster, and thereby 
virtually his servant and agent, and as the managers of the races were in possession of a sufficient sum of money belonging to $\mathrm{Mr}$. Dockeray to cover Lyster's stake, it was quite sufficient to meet the objection, and that Lyster was entitled to receive.

24.-Whether a Horse is considered a Winner if the Stake does not appear in the Official Calendar.

'Tunbridge Welus, 1838.-The Stewards' Stakes of $3 l$. each, with $40 l$. added; a winner in 1838 to carry 31b.; twice, 5lb. extra.

Mr. Cassidy's f Maid of Hertford $\quad \begin{array}{llll}2 & 1 & 2 & 1\end{array}$ Capt. Pearson's g Muuchausen $4 \begin{array}{llll}4 & 3 & 1 & 2\end{array}$ Mr. Shelly's Magnolia • • • 12123 Mr. Bacon's Elizabeth • . . 34440

An objection was made against Maid of Hertford, that she only carried 3lbs. extra instead of 5lbs., she having won a plate at Norwich, and the Hertfordshire Stakes, a handicap, at Hertford. Mr. Cassidy, in reply, stated that she had not won a plate at a public meeting, the Norwich Races being on the terms of private races; and secondly, that the Herefordshire Stakes being a handicap, he conceived that handicaps and matches were always excused. 
The stewards of the Jockey Club decided in favour of the Maid of Hertford only carrying one extra penalty, in consequence of the Norwich Races not being advertised in the official ' Racing Calendar,' coupled with the fact that the Norwich Plate was an illegal race, being under the value of $50 \mathrm{l}$.; but the second plea was not tenable, inasmuch as winners of matches and handicaps are never excused from carrying extra weights unless so particularly specified.

\section{5.-Involuntary Jostle.}

\section{'Thursday, First October Meeting, 1797.}

Lord Clarendon's c by the Arcot Arabian and Sir C. Bunbury's Poplar started for a match. Lord Clarendor's colt came in first; but Sir C. Bunbury's rider complaining that he was jostled, the matter was referred to the stewards, who determined that the race should be given to Sir C. Bunbury; but it appeared to them that the jostle was involuntary, and no blame was imputable to Lord Clarendon's rider.

$$
\text { Signed (per order), E. WEatherby. }
$$




\section{6.-Foul Riding.}

Yonk, July '28, 1714.-Her Majesty's Gold Cup, value $100 \mathrm{gs.}$, for six year old horses, 12st. each. Four-mile heats.

Mr. Childer's b m Duchess, R. Hesseltine 12221 Mr. Pierson's b h Foxhunter, S. Jefferson 21112 Mr. Young's gr g Shy . . . . . 3340 Mr. Moore's b h Dragon . . . . . 4430 Mr. Hutton's g h Ironsides . . . . .65 dis. Mr. Dawson's d h Pretender . . . .5 6 dis.

The riders of Duchess and Foxhunter having been guilty of foul riding in the third heat, it was agreed that those two should run for the heat again, when Duchess won.

Mr. Pierson still claiming the plate, a lawsuit followed, and it was decided by the Court that all the horses which were not distanced had an equal right to the prize.

\section{7.-Foul Riding and Fighting.}

YoRK Meeting, September 14th, 1709.-50l. Plate; the best of heats.

Mr. Welburn's br h Button . 130

Mr. Walker's br m Milkmaid. $3 \quad 1 \quad 0$

Mr. Graham's gr h Brisk . . $2 \quad 2 \quad 3$

Mr. Megson's ch h Raffle . . 4 dis. 
The third heat terminated in a dead heat between Button and Milkmaid; but the riders being guilty of foul play in riding, and afterwards fighting on horseback, the plate was given to Mr. Graham's gr h Brisk.

28.-One Horse Jostling, and the other's Jockey Striking him.

['The Duke of Grafton and Lord Grosvenor's decision on the match between Tuscan and Dilettanti.] -It appeared in evidence that the rider of Tuscan, who came in first, jostled and crossed Dilettanti, whose rider struck him.

Judgment: "We are of opinion that Lord Claremont would have been entitled to the match if his rider had not lost all claim to it by striking Mr. Walker's rider before he passed the endingpost. We therefore think that both sides having forfeited, the match ought to be void."-October, 1778.

\section{9.-A Cross-Claret-Newmarket.}

Newmarket, 1831.-The Claret Stakes, 200, h ft.; the owner of the second horse to save his stake.

Amphiaraus . . . . . . 1

Captain Arthur, Augustus, Cetus, and Little Red Rover also started, but were not placed. St. 
Nicholas also started and came in first; but a cross having been complained of and established, he was disqualified, and the race was adjudged to Amphiaraus, the second horse; and no other horse being placed a question arose whose owner could claim to withdraw his stake.

The stewards of the Jockey Club decided that the disputed stake should be divided amongst the owners of the other horses, exclusive of the winner and the disqualified horse.

30.-Complaint of Crossing not Made in Time. Canterbury, 1821.-City Plate, 507.

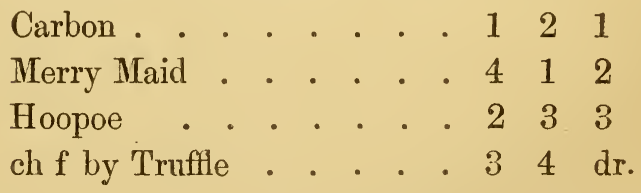

A charge of foul riding brought against the jockey who rode Carbon induced the stewards of the races to give the third heat to Merry Maid; subject to a reference to the stewards of the Jockey Club.

The stewards of the Jockey Club determined the race in favour of Carbon, agreeably to their former decisions, on this ground: that all complaints of crossing are required to be made before the jockeys are weighed; whereas the present 
complaint was not brought forward until a considerable time after.

Original case, Lord Claremont versus Lord Egremont. October, 1795.

31.-Swerving not Intentional-Allowed to Start again.

Basingstoke, 1819.-Handicap Sweepstakes, $5 l$. each, with 25l. added. Heats.

Beppo • • • . . . . 11001

Brother to Coy . . . . . 213

Blue Ruin . . . . . . 432

Marksman . . . . . $3 \mathrm{dr}$.

Beppo came in first the second heat, but a complaint being made against the rider for swerving and jostling Brother to Coy, the heat was given to the latter. An objection was then made to Beppo starting again; but the rider having declared that the swerving was not intentional, he was allowed to start his horse again, subject to the decision of the Jockey Club.

The stewards of the Jockey Club declined to interfere, observing that the fact of the jostle could be determined only on the spot and at the time; that if a jostle had been proved, Beppo was distanced and should not have been allowed to start 
again; if the contrary, he was entitled to the race without winning a third heat.

$$
\text { Signed (per order), } \quad \text { E. W. }
$$

32.-Running Wrong Side Post.

Burton-upon-Trent, 1817. - Handicap Sweepstakes, with $30 l$. added.

Mervinia . . . . . . . 410

Catherine . . . . . 120

Pankakon . . . . . . 343

Algerine . . . . . $2 \mathrm{dr}$.

Mermira came in first the third heat; but a charge being preferred against her of running on the wrong side of a post, and the evidence pro and con. being nearly equal, the stewards decided that the stakes should be divided between Mervinia and Catherine.

33.-Running Wrong Side Post-Complaint not Made in Time.

Enfield Races, September 20th, 1803.

Mr. Dockeray's Rosebud . . 311

Mr. Pearcy's b h Omnium 132

Rosebud ran on the wrong side of the post the first heat, but no complaint was made to the steward till after the second heat; they then com- 
plained, and it was left to be decided by Sir C Bunbury.

"Sir C. Bunbury and the committee of the Jockey Club are of opinion that Rosebud is entitled to the plate, as no complaint was made till after the second heat.

$$
\begin{aligned}
& \text { "Signed (per order), } \\
& \text { "E. Weatherby." }
\end{aligned}
$$

34.- One Horse Driving Another on the Wrong Side of Post.

TAvistock Races, July 31st, 1810.-A 50l. Plate, for all ages. Three-mile heats.

Capt. Weir's White Rose • $0 \begin{array}{lll}0 & 1 & 1\end{array}$

Sir W. Call's Red Cross Knight $14 \quad 2$

Mr. James's Tekeli . . . . 223

Mr. Handley's Trinculo . . $33 \mathrm{dr}$.

In the first heat Trinculo crossed White Rose, and drove him on the wrong side of a post.

The stewards allowed both horses to start again, subject to the opinion of the Jockey Club whether White Rose was distanced or not, having been driven out of the course by the foul riding of Trinculo's jockey.

By the decision of the stewards of the Jockey Club the horses will stand thus :- 
Red Cross Knight . . . . 121

Tekeli . . . . . . . 212

White Rose . . . . . . dis.

Trinculo . . . . . . dis.

35. Whether the Second Horse Distanced can

Receive Entrance Money.

For a Plate, the horses came in as follows:-

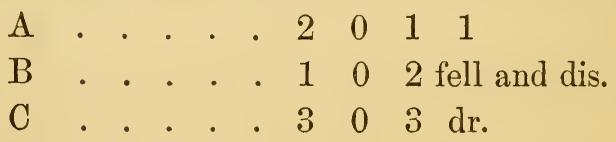

Question: Whether B was entitled to the entrance money as second horse?

The stewards of the Jockey Club decided that $\mathrm{B}$, being distanced, was not entitled to receive the entrance-money. (1798.)

Remarks: The second heat being a dead heat between the three, went for nothing; otherwise a horse cannot be distanced in a fourth heat.

36.-All the Horses going on the Wrong Side.

Pytchlex Hunt, 18:38.-For the Trial Stakes, Compensation, Gadfly, ch g by Defence, Shylock, and others started, but were not placed. A charge was made that every horse went on the wrong side of a post at some part of the race. So much 
conflicting evidence was produced that the stewards postponed the investigation till the following day, and decided that each subscriber should withdraw his stake, and the race be considered void.

37.-Crossing-York, 1818-Extraordinary

Decision.

For the County Cup at York, 1848.

Dough, 3 yrs., 6st. 11lb. . . . . 1 .

Miss Sarah, 6 yrs., 8st. 5lb. . . . 2

Rowena, aged, 7st. 7lb. . . . . 3

Lecomte, 3 yrs., 7st. 5 lb. . . . . 4

The horses came in as above, but on coming to scale Flatman, the rider of Miss Sarah, complained that the rider of Dough crossed him. The rider of Rowena complained that both jockeys had crossed him.

This case was heard by the stewards of York, who decided that Rowena was entitled to the race.

Remark: The most extraordinary decision in the annals of racing. It was admitted that Dough crossed and jostled Miss Sarah, driving her across the natural track which Rowena would have taken. So Miss Sarah was doubly punished; first she was ill-treated by Dough; and then disqualified by the stewards because she was driven out of her place 
without the slightest blame being attached to her jockey.

38.-A Horse Scratched out of his Engagements obliged to Pay the Whole Stake.

In the Bedford Stakes at Newmarket, October, 1847, Lord Spencer struck the Empress out of this race a short time before the races commenced; but the trainer not being aware of this circumstance started her.

A question rose as to whether Lord Spencer was liable to pay the whole stake, or only the forfeit.

The stewards decided that he must pay the whole stake.

Remark: With all due submission, I assert that this decision was in direct violation of racing law. Empress having been struck out was virtually defunct. If she had come in first she would not have received the stakes: and if she had been backed at the post, the bets would have been null and void; she was therefore to be considered as an intruder, and liable to be fined $5 l$. for galloping with the leading horses in a race.

A public notification that Lord Spencer had Empress scratched appearing in the window of Mr. Weatherley's office before the races commenced. 
39.-Loutherbourgh Case.

After the Goodwood Stakes, 1838, the owner of St. Luke, the second horse, objected to Loutherbourgh, as having been improperly entered, and described as a colt by Mameluke, his dam, foaled in 1828, by Smolensko, out of Miss Chance, by Trinidad, under which description he had run for a plate at Goodwood in the preceeding year. It appeared that this colt had been described and entered in three two year old stakes as by Camel, out of Fanny, by Phantom, dam by Skim; and secondly as Fanny, sister to Fashion, and had been disqualified from winning, owing to the misrepresentation. It appeared in evidence that he was properly described in the Goodwood Plate; and that if no objection was made to his age, the seventeenth rule could not be applied to the case, as the horse had started before.

The two year old stake won by Fanny was given up to the Duke of Richmond's Conciliation upwards of seven years after the event transpired, owing to the proof of Fanny being improperly named. 


\section{0.-Incorrect Nomination.}

The opinions of the stewards of the Jockey Club were asked on the following case, which had been decided by the Irish Jockey Club:-

The Earl of M. had declared the produce of Pasta covered by Drone, as a bay filly, then named Zelmyra. In the following month of January the name had been misprinted into Zulima, and Lord M. having another filly called Zulima, he wrote to name Zelmyra for the Stewards' Stakes, as Zelmyra, sister to Argirio.

In 1839 Zelmyra, by Drone, out of Pasta, started for the Anglesea and another stake, but did not win. On Saturday in the same meeting she ran for the Stewards' Stakes, also as Zelmyra, but with sister to Argirio added. She was objected to, as Argirio was by Roller or Drone, out of Pasta; and the objection was confirmed.

A similar case occurred at Newmarket. A filly by Whalebone out of Moses's dam, was entered as a sister to Moses, and disqualified, as Moses was got by Whalebone or Seymour.

41.-Declining to Receive Evidence on Misnomination.

The following nomination was made for a Produce Sweepstakes at Ascot:- 
"Lord Tavistock's Sister to Benedick, covered by Middleton." There being two sisters to Benedick, the nomination was incomplete, according to the seventeenth rule. Lord Tavistock ascertained that the other sister to Benedick was sent abroad some time before the stake closed, and submitted that the circumstance sufficiently identified his nomination.

The stewards of the Jockey Club declined to go into evidence of this nature, and decided that the nomination was invalid.

Remark: This is a very injudicious selection of an adjudged case. There was no reason why the stewards should have declined receiving evidence, because it might have been proved that the sister to Benedick sent abroad was actually dead at the time the stake closed.

\section{2.-Similar Case-Evidence Received.}

A question was submitted to the stewards of the Jockey Club in the Craven Meeting, 1840, as to the qualification of the Duke of Portland's Beiram colt to start for the 200l. Stakes on Friday in that meeting, for which stakes he was entered as a b c by Beiram, dam by Reveller, out of Veil. Veil had produced two fillies by Reveller, one foaled in 
96

Horse Racing.

1831, which was the dam of the Beiram colt; the other in 1832.

It was proved to the satisfaction of the stewards that the latter mare was not living when the Beiram colt was born, and they therefore decided that the nomination was ralid.

43.-Whether a Horse was Entered in Time, according to the Articles.

Huntingdon, 1838. - It was advertised that " all horses, \&c., named for the Cup Stakes, Sweepstakes, or plates, must be shown and entered before the clerk of the course on the Saturday, August 11th, preceding; at the Crown Inn, Huntingdon. Horses, \&c., having run in the previous week at any meeting seventy miles from Huntingdon are not required to be shown."

Romania, having run at Goodwood on Thursday, August 2nd, did not show at the time appointed, and ran for the Cup Stakes. Query: was Romania entitled to start, nine days having elapsed between her race at Goodwood and the day of entrance?

It was decided that Romania was entitled, she having run at Goodwood on the previous week to the day of entrance at Huntingdon.

Another objection was made to the horse Bravo 
starting for the plate, as he had not been shown on the preceding Saturday; but it appearing he was post-entered, it was decided he was eligible, post-entrance placing the horse on a different footing.

44. - A Stake Illegally Re-opened as the Original Stakie.

Taunton, 1838.-A Hurdle Race Sweepstakes, 10l. each, $3 \mathrm{ft}$., if declared before eight o'clock the evening before starting; 20l. to be added from the fund if three horses start. Closed with three subscribers, A, B, and C. C paid forfeit by the prescribed time; $A$ and $B$ then agree to admit D before starting; $\mathrm{C}$ objected to its being considered the original stakes, and claimed to have his forfeit returned.

It was decided that the stakes could not be reopened without the consent of $\mathrm{C}$, and that he was consequently entitled to have his forfeit returned.

45.- Jockey Dismounting before he Passed the Winning-post Allowed to Start again.

[Corresponding to No. 1, 'Racing Calendar.']The Hoo Races, 1779. Subscription 10 gs. each, for ponies not exceeding thirteen hands. Two-mile 
heats. Twelve hands carrying 6st.; weight for inches.

Mr. Walker's gr Arethusa, 6st. 12lb. . 2311 Lady F. Radcliffe's ch c Mon Mie, 6st. 12lb. 3132 Lord Melbourne's gr m, 6st. 12lb. . . $122 \mathrm{dr}$

Arethusa's rider having saved his distance the second heat, dismounts between the distance-post and the ending-post: but re-mounts, rides past the ending-post, and weighs as usual; starts and wins the third heat, and weighs without any objection being made. Lord Melbourne's gr m being second the third heat, he demands the stakes, not knowing till then that Arethusa's rider had dismounted, and refuses to start for the fourth heat.

The stewards of the Jockey Club decided that no objection having been made to Arethusa's starting for the third heat she was entitled to the prize.

46.-Two Horses Running for a Plate belonging to the Same Owner.

At Canterbury Races, 1829, for the $100 l$. given by the noblemen and gentlemen, Mr. Pearce's Guildford won the two first heats ; but Mr. Mattam, the owner of Moor Buzzard, claimed the plate, alleging that Guildford was disqualified, his 
owner having run two horses for a prize for which heats were run.

1: It was contended, on the part of Mr. Pearcefirst, that this was not a plate; secondly, that no objection was made till after the jockeys were weighed and the horse led away.

The stewards of the Jockey Club were of opinion that Moor Buzzard was entitled to the prize, and referred to the rules of Racing, No. 40.

The owner of Guildford was liable by Act of Parliament to the penalty of losing his horse, in addition to losing the plate.

\section{7.-Hunters' Certificates not Produced-Both Disqualified.}

Tenbury, 1822.-Dweepstakes 5 gs., with a prize added for hunters not thorough-bred.

Mr. Aston's b $\mathrm{g}$ by Sir Sampson, 6 yrs.

Mr. T. Pickernill's b g Sylvan, 4 yrs.

The certificate of Sylvan not having been produced until ten minutes after the time specified, and that of the other not having been satisfactory to the stewards, both horses walked over the course, and the matter was referred to the Jockey Club.

The stewards of the Jockey Club determined 
that as neither Mr. Aston nor Mr. T. Pickernill had complied with the articles relative to certificates, neither horse was entitled to the stakes.

48.-Whether a Hor'se, the joint property of the Subscriber and a Confederate, not a Subscriber, can start without Paying Extra Entrance for a Private Stake.

Newmarket October, 1818.-Sweepstakes $5 \mathrm{gs}$. Beacon Course.

By a condition in the articles the horses were to be the property of the subscribers, or pay $50 \mathrm{gs}$. entrance.

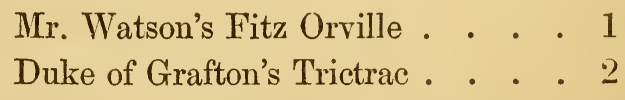

It appeared that Fitz Orville was the joint property of Mr. Watson and Mr. Tibbet, the former of whom was a subscriber to the stake; and a question arose whether a horse the joint property of a subscriber and another gentleman his confederate, not being a subscriber, could start without paying $50 \mathrm{gs}$. entrance.

The stewards of the Jockey Club decided that the subcriber had a sufficient interest in the horse to qualify him to start without paying any entrance. 
49.-In Running Heats a Horse bolted and Threw his Rider-not Distanced, because there was no Distance-post.

Heaton Park, 1830. - Sweepstakes 10l. each, for horses belonging to the officers of the Queen's Bays.

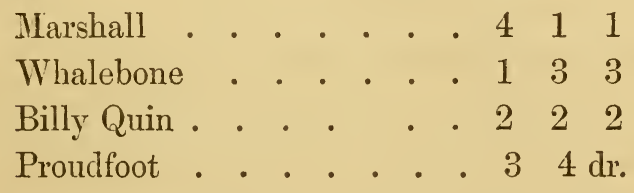

Marshall bolted in the first heat and threw his rider; but as there was no distance-post he remounted, came into the course where he had left it, and brought in his weight.

The stewards, on an objection being made, decided that he had a right to start again.

Remark.-The decision was perfectly correct, for in rumning heats a horse cannot be distanced for being out of his ground, except by a person stationed at the distance-post for that specific object. 
50.-A Horse Disqualified from Arrears of Forfeits.

Warwick, 1830.-The Guy Stakes, 50l., h ft, for three year olds. One mile.

Mr. Beardsworth's Birmingham . . 1

Sir Mark Wood's Cetus . . . . . 2

Sir T. Stanley's Lawrie Todd . . . 3

The owner of Cetus claimed the stakes on the ground that the subscriber in whose name Birmingham was originally entered, had not paid all his arrears of forfeits.

The question was referred by the stewards of the races to the stewards of the Jockey Club, who decided that Cetus was entitled to the stakes. This was afterwards confirmed in a court of law.

51.-A Horse Disqualified for not having Made Stakes.

Workington, 1830.-Sweepstakes 5l. each, with $50 l$. added ; the second horse to receive $15 l$.

Mr. Hodgson's George IV., 3 yrs. • . 551 Mr. Jewell's b c by Frolic, 4 yrs. . . 144 Mr. Simpson's Young Duchess, 6 yrs. . $2 \quad 3 \quad 2$ Mr. Thompson's $\mathrm{b} m$ by Teddy, aged . $\begin{array}{lll}4 & 2 & 3\end{array}$ Mr. Williamson's Push-forward, 3 yrs. $3 \quad 5$ dr. 


\section{Racing Cases.}

Three objections were made to the plate being paid to Mr. Hodgson-first, that Mr. Hodgson and Mr. Williamson were confederates, and therefore not entitled to start two horses in a race for which heats were run; secondly, that George the Fourth was more than three years old; thirdly, that Mr. Hodgson had not paid the stakes and entrancemoney according to the conditions of the race,which fact was admitted in the statement sent to the stewards of the Jockey Club.

The stewards of the Jockey Club decided on the third objection, that $\mathrm{Mr}$. Hodgson was not entitled to the prize; and that no other horse having won two heats, the race was null and roid; and that no person could olaim the sweepstakes and the 507., or the $15 l$. for second horse. The first two objections being questions of fact, the stewards declined to take them into consideration.

The stewards of the Jockey Club disqualified Mr. Ashmole's Smallhopes for the Ascot Cup, 1811 , for having failed to make stakes. Janette, who was second, received the cup; Turtle the 20 gs. as second horse; and the bets were settled as if Smallhopes had been the winner. 
52.-A Horse Entered after the Time, and not Objected to by the other Subscribers.

EGHAM, 1838. - Ankerwycke Stakes.

Mr. Balchin's b f Slender • . $3 \begin{array}{lll}3 & 1 & 1\end{array}$

After the first heat, Mr. S. Day made an objection against Slender, she having been entered ten minutes after the hour named for closing the stakes, without his sanction or knowledge.

It appeared that the Clerk of the Course informed Mr. Balchin that it was past the hour, and that he could not enter the filly without the consent of the company present, who consisted of the owners or grooms of the respective horses entered, including Mr. S. Day's groom. No objection being made, she was entered; and owing to $\mathrm{Mr}$. S. Day not making his complaint until after the first heat, the objection was not considered valid.

53.-Winning Jockey not Weighed, and Horse consequently Distanced.

Yarmouth Races, 1813. Sweepstakes $10 \mathrm{gs.}$ each, with 50l. added. Two-mile heats.
Sir C. Bumbury's Scout • . . $22 \quad 2 \quad 1 \quad 1$
Lord Suffield's Huntingdon - 31 dis.
IIajor Wilson's f by Selim . . $13 \mathrm{dr}$. 


\section{Racing Cases.}

Huntingdon came in first in the third heat, but fell after passing the winning-post, and the rider being much hurt was carried away without being weighed.

5t.-A Person having a Share in a Second Horse Running for a Plate.

Kinutsford, 1838.- - The Ladies' Purse.

Ir. Marlow's Fair Play • • . . . 11

MIr. Allen's Vesper . . . • . . 42

Mr. Ashley's Clithero . . . . . 33

Lord Derby's Miss Bowe . . . . 2 dr.

Vesper walked over for a third heat, and claimed the prize on the ground that Mr. Marlow had started two horses.

It was proved that Mr. Marlow had a share in Clithero, and consequently the plate was given to Vesper:

55.-Chathan Plate-Whether a Horse which Wins subsequently to his Entry is to Carry Extra Penalties for Winning.

For the Chatham Plate the winner of a stake or plate in 1825 was to carry $7 \mathrm{lbs}$. extra; and the question was, whether a filly which had won a plate subsequently to the entering for the Chatham 
Plate, but previously to the running for it, was to carry 7 lbs. extra.

The stewards of the Jockey Club gave it as their opinion that she was not obliged to carry $7 \mathrm{lbs}$. extra, and that a horse being duly qualified at the expiration of the time of naming or entering for a stake or plate should not be affected as to that stake or plate by any subsequent event.

It is a curious fact that the Jockey Club gave a contrary decision against Mr. Batson's Cecilia, who omitted to carry $3 \mathrm{lbs}$. extra, as the winner of a plate the day before, which was subsequent to her entry for the plate in dispute; but all similar cases have been recided as above.

At Newmarket in 1786, Quibbler, 6 st., carrying feather weight, ran 23 miles in $57 \mathrm{~m}$. 10 sec.

At Newmarket in 1763, Cabbage, 13 st. 7 lb., beat Trinket, 13 st., five times round the R. C.:-

M. S.

First round in . . . 120

Second do . . . 1046

Third do . . . . . 117

Fourth do . . . . 1042

Fifth do . . . . 1055

Total $\overline{5530}$ 


\section{( 107$)$}

Betting Cases.

1.-A Bet on a Double Event-Second Event Compromised.

Lord Claremont betted $500 \mathrm{gs}$. to 100 gs., p.p., that Quill did not beat Seraphina and Pantaloon. MIr. Burlton's Quill beat Seraphina, and paid $60 \mathrm{gs}$. compromise to Mr. Vernon's Pantaloon.

Decidèd :- " Lord Clermont wins 100 gs.

$$
\text { "(Signed) }
$$

“April 24th, 1771.
ANCaster.

C. Bunbury.

J. WASTELL."

2.-A Case of Collateral Betting.

Previous to the First October Meeting at Newmarket, 1789, H betted C 50 gs. on Johnson winning his battle against Perren versus Skyscraper beating Magpie. Johnson beat Perren; Magpie paid forfeit to Skyscraper.-Query: how does the bet stand?

$$
\text { (Signed) H. C. Combe. }
$$

"The stewards of the Jockey Club are of opinion that the bet is void."-October 17th, 1789 . 
3.-Winner Disqualified.-Bets go to Second Horse.

A takes $50 \mathrm{gs}$. to $10 \mathrm{gs}$. of $\mathrm{B}$ that his horse wins a sweepstakes. His horse is second in running, but proving the horse that beat him was not qualified, he received the sweepstakes from the person whose horse came in first. Query: Is A entitled to win his bet?

Answer: "The stewards of the Jockey Club are of opinion that the horse which came in second, and to whom the sweepstakes was given up, on proof that the first horse was disqualified, must be deemed the winner, and consequently B looses $50 \mathrm{gs}$.

"Signed (per order),

"October 30th, 1781.

E. W."

\section{4.-Horse, if Disqualified, Bet Off:}

A bets $\mathrm{B} 50 \mathrm{gs}$. to $20 \mathrm{gs}$. that $\mathrm{C}$ and $\mathrm{D}$ do not both win. $\mathrm{C}$ wins, but $\mathrm{D}$ was disqualified from starting, as it was a maiden plate, and he had previously won. Query: Does A win the $20 \mathrm{gs.}$, or is B entitled to a part of the $50 \mathrm{gs}$.?

Answer: "If D was qualified at the time the bet was made $\mathrm{A}$ wins, but if $\mathrm{D}$ was disqualified at the time then the bet is off.

$$
\text { "Signed (per order), } \quad \text { E. W." }
$$




\section{Betting Cases.}

\section{5.-Second Case of Collateral Betting.}

Mr. Bullock betted Sir F. Standish $100 \mathrm{gss}$. that Royalist won his two matches against losing them. Royalist won the first match, the second match was off by consent. Query: How is the bet to be determined?

Answer: "The stewards of the Jockey Club are of opinion that Mr. Bullock wins half his bet. "Signed (per order),

$$
\text { E. W." }
$$

\section{6.--A Bet Declared Off after the Event.}

A bets B $15 \mathrm{gs}$. to $10 \mathrm{gs}$. that Knowsley beat Worthy the first time they meet; B, supposing the horses would not meet before the Newmarket Meeting in October, wrote on the 24th September, 1800 , to A, begging to be off the bet, as he could not go to Newmarket. The above horses had run on the 19th of the same month at Burford, where Worthy beat Knowsley. On the 29th September $\mathrm{B}$ received a letter from a Mr. Dollan, a friend of A's, saying that according to his request the bet should be off. Query: Is the bet off, it having been decided previous to B's application to A ? 
Answer: "The bet must stand, as the race was determined before the compromise was proposed.

“25th April, 1801. "Signed (per order),

7.-A Double Bet-First Event Lost, Second Off by Consent.

A betted B 10l. to $8 l$. that Whale did not win either the Garden Stakes or the match with Beiram. Whale was beaten in the Garden Stakes, and the match with Beiram was off by consent. Query : Is A entitled to receive or not?

Answer: "The money must be put together and divided."

Remark: Some persons have considered this an erroneous decision, because $A$ after winning his first event loses $1 l$., but it is strictly correct according to law and equity; the second event being off on even terms was equivalent to a dead heat. If A had taken 20l. to 107 ., which probably was the right betting, instead of laying 107. to 8l. on the two events, he would have won $5 l$., but by making a bad bet he suffered the penalty.

8.-A Horse wrongly Described-Bets not Paid.

2 to 1 was laid on Turquoise against Elinor for the Oaks. Elinor being improperly named as 


\section{Betting Cases.}

-

Elinor, by Gustarus, was not allowed to start. The question whether the bet was to stand or not was submitted to the stewards of the Jockey Club, who referred it to a general meeting, at which it was ultimately decided that the bet was void.

Remark: This decision is of great importance; it rests on the principle that if you can't win you cannot lose, and on the fact that there was no such animal as the Elinor, by Gustarus, described in the Oak Stakes.

\section{9.-A Bet improperly Declared Off.}

Mr. S. claimed to have taken 100 to 5 of Mr. R. in 1827 that Matilda would win the St. Leger.

The defence was that the bet was so illegibly entered by Mr. R. in his book, that he had written to Mr. S. to know if he had made such a bet, and receiving no answer, had declared the bet off at Doncaster.

It appeared in evidence that $\mathrm{Mr}$. S. has answered both the letters of $\mathrm{Mr}$. $\mathrm{R}$. to the address given, but that they had been refused and not called for, and returned through the post-office.

"The stewards of the Jockey Club are of opinion that MIr. S. is entitled to receive the bet of Mr. R.” 
10.-A Dead Heat-Stakes Divided-Bets Paid in Proportion.

The Duke of Rutland and Mr. Wyndham, whose filly and colt ran a dead heat for a sweepstakes in the Craven Meeting, 1822, agreed to divide the stakes: but it being necessary for one of the horses to walk over, a doubt arose as to the mode of settling bets, and the following cases were submitted to the Jockey Club:-

First-A bets B 5 to 2 on the field against one of the horses which ran the dead heat; secondly, $\mathrm{A}$ bets $\mathrm{B} 5 \mathrm{l}$. on the field against the other horse which ran the dead heat; thirdly, A bets B 3 to 1 that one of the horses which ran the dead heat, and Augusta in the Claret, did not both win.

The stewards decided that in the first and second cases the money betted must be put together and divided; and in the third case that the dead heat being the first event the bet thereby became roid.

\section{1.-A Similar Case-Heats-Sweepstalies Divided -Bets Ditto.}

For the Lansdown Stakes at Bath, Mrs. Day's Brother to Lusher, Mrr. Sadler's Achilles, and Mir. Wreford's Wilna had each won a heat; Wilna was then drawn; Mrs. Day and Mr. Sadler agreed 
to divide the Stakes, and Brother to Lusher walked over.

Two questions were submitted to the stewards of the Jockey Club, who decided-first, that the bets should be put together and divided in the same proportion that had been agreed upon in respect of the stakes; secondly, that Brother to Lusher must carry extra weight on future occasions as the winner of this race.

Remark: Achilles was equally liable to carry extra weight as Brother to Lusher in any subsequent race where such penalty was imposed on the winner of a sweepstakes. The act of walking over makes no distinction where the parties divide equally.

12. - A Bet Lost not allowed to be Paid to a Third Party.

A admitted that he had lost $100 l$. to B; but declined paying it because he intended paying it to C, who had a claim on B for $100 l$.

The stewards decided that A must pay the $100 t$. to $\mathrm{B}$ forthwith, as no transfer could take place without the consent of both parties. 
13.-A Disputed Bet Decided by the State of the Odds.

Mr. S. had taken a bet of 20 to 2 that Scroggins and Elis would be first and second for the St. Leger, which Mr. B. refused to pay, alleging that Mr. S. had placed Scroggins first and Elis second. This was contradicted by Mr. S.'s witness, whose testimony was corroborated by the state of the odds.

The stewards of the Jockey Club decided that Mr. S. was entitled to receive the bet from Mr. B.

\section{4.-Disputed Bet.}

This was a case of a bet on the Coffee Room Stakes, on which Mr. D. claimed to have taken of Mr. H. 20 to 5 about Vespertilio. Mr. H. maintained, on the contrary, he had betted the complainant 20 to 5 against Mr. Vansittart's filly.

After hearing evidence the stewards gave it as their opinion that there was a mistake between the parties, and that neither party should pay or receive.

15.-A Bet whether any Horse ever Ran a Mile in a Minute.

The following case, the subject of a bet, was submitted to the stewards:- 
Query: "Whether any horse according to any authentic documents ever ran the space of one mile in one minute of time? Signed, Thomas Hurst, and JoHN Ives."

Answer: "There is no authentic document of any horse having run one mile in one minute of time; and the report of Childers having done so is not believed. Signed (per order),

“24th April, 1801.

E. W."

16. - A Bet on Placing First and Second-A Dead Heat for Second.

At the Goodwood Races, 1838, A betted B 25 to 10 that in the Sweepstakes, gentlemen riders, Reuben and Caliph would not be first and second. The result was

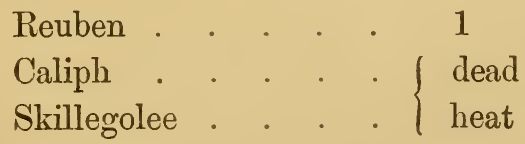

Query: How is the bet decided?

Answer: The stewards were of opinion that this case must be put on the footing of two events or matches, where the first event was won and the second event terminated by a dead heat; they therefore recommended that the money should be put together and divided. 
17.-Money Given for a P.P. Bet-Horse

\section{Disqualified.}

B gave D 2 gs. for the call of $40^{\circ}$ gs., p.p. in a sweepstakes between their horses.

Query: “Will D's horse being disqualified authorize him not to pay B the $40 \mathrm{gs}$., though B started his horse and the other did not.

Resolved by the stewards of the Jockey Club that "if the articles of the sweepstakes alluded to were publicly known at the time the 2 gs. were given for the call of $40 \mathrm{gs}$. p.p. and no subsequent alteration tending to disqualify B's horse was made in them, that $B$, who started his horse, is entitled to the $40 \mathrm{gs}$.

"Signed (per order),

"Friday, Oct. 2nd, 1777. E. Weatherby."

\section{Epsom, 1796.}

18.-Horses having started, Compromise repudiated.

Lord Clermont's Hornpipe beat Lord Egremont's Atropa, Derby course, $50 \mathrm{gs}$. This match was compromised by Lord Egremont paying $3.5 \mathrm{gs.}$; but the fillies had started and run two or three hundred yards before the jockeys were informed of the compromise. Atropa's rider then pulled up, but having started, it was considered a race and the full money paid. 
19.- The owner of a second horse claiming the bets, because the winner's number did not appear on the Telegraph board.

Ascot, 1863.-Fern Hill Stakes.

The jockey who rode Tomato weighed after the usual time, and Hippolyta's number appeared on the board by mistake instead of Tomato. The owner of the second horse objected to Tomato receiving the stakes and the bets on that ground; but in the absence of any law to make the objection valid, the stewards decided that Tomato was the winner, and it was subsequently determined that the proposal to transfer the bets to the second horse was in violation of the 2 nd Rule of Betting.

20-Objection made after the Race.

Claxton, which had been scratched on the 1st of August in the 'Racing Calendar' by his former owner, appeared coloured in the Huntingdon card, and was allowed to start on the representation of Mr. E. Parr, that he had bought the horse on the 2Sth of July, with his engagements. Lord St. Vincent subsequently declared that when he sold the horse no mention was made of engagements, and Mr. E. Parr having failed to produce the 
written acknowledgment required by Rule 34, Suspicion, the second horse, received the stakes, and the bets, by Rule 2, were paid to Claxton, owing to no person making an objection to him before starting. 


\section{( 119$)$}

By Order of Her Majesty's Master of the Horse, the following Queen's Plate Articles are substituted for those hitherto in force.

January, 1861.

\section{QUEEN'S PLATE ARTICLES.}

[It is Her Majesty's Command, that these following Rules be observed by the Owners and Riders of all such Horses, MIares, and Geldings, as shall run for Her MLajestry's Plates at Newmarket and elsewhere.]

I. Every horse, mare, or gelding, that runneth for any of the said Plates, shall carry the weight appointed in the Schedule hereunto annexed.

II. Every person that putteth in a horse, mare, or gelding, for any of the said Plates, shall enter the same with the name of the owner, and the age, name, pedigree, or sufficient description of the horse, according to the Rule of the Jockey Club regarding nominations, at the time and place appointed by the Steward or Stewards of the Races at which such plate is to be run for. The charge for such entry shall not exceed five shillings, and no further charge shall be made on the winner of the Plate. 
III. Horses that run for any of her Majesty's Plates shall start at the time appointed by the Steward or Stewards of the Races at which such Plate is run for.

IV. Each horse's, mare's, or gelding's place, as he or they come by the ending-post, shall be determined by the Judge appointed by the Steward or Stewards of the Races at the place where the said Plate is run for.

V. Every rider shall, immediately after the race be run, be obliged to come to the usual place of weighing, with his horse, mare, or gelding, then and there to alight, and not before, and there to weigh to the satisfaction of the person appointed for that purpose.

VI. And in case of neglect or refusal thereof, such owners and riders shall immediately be declared incapable of running or riding any more for this or any of her Majesty's Plates hereafter.

VII. No horse, mare, or gelding that runneth on the wrong side of the post or flags shall have any claim to the said Plates.

VIII. None of her Majesty's Plates to be run for in heats.

IX. When the age or qualification of a horse entered for any of her Majesty's Plates shall be objected to, either before or after running, the Stewards of the Races at which such Plate is run for shall have the power to order an examination of the horse's mouth by competent persons, and to call 
for all such evidence as they may require, and their decision to be final unless they shall think fit to refer the matter to the Stewards of the Jockey Club for the time being, in which case the decision of the said Stewards of the Jockey Club shall be final. A Certificate shall not be granted to any horse objected to until the question of his qualification shall be decided in the manner herein prescribed.

X. Her Majesty's Plates to be run for between the 25th of March and the 15th of November, both days inclusive, in each year.

XI. The distance shall not be less than tro miles, and the weights, regulated according to the months in which the races are run, are to be according to the subjoined Schedule.

XII. And in case any difference shall arise in running, or respecting any matters not hereinbefore provided for, or as to the intrepretation of these her Majesty's orders, the same shall be determined by the Master of the Horse, or by such person or persons as he shall appoint.

(Signed) AmLesburt,

Master of the Horse.

N.B.-One of the Newmarket Plates, the Plate at Epsom, and that run for alternately at York and Richmond, are for mares only, as heretofore. 


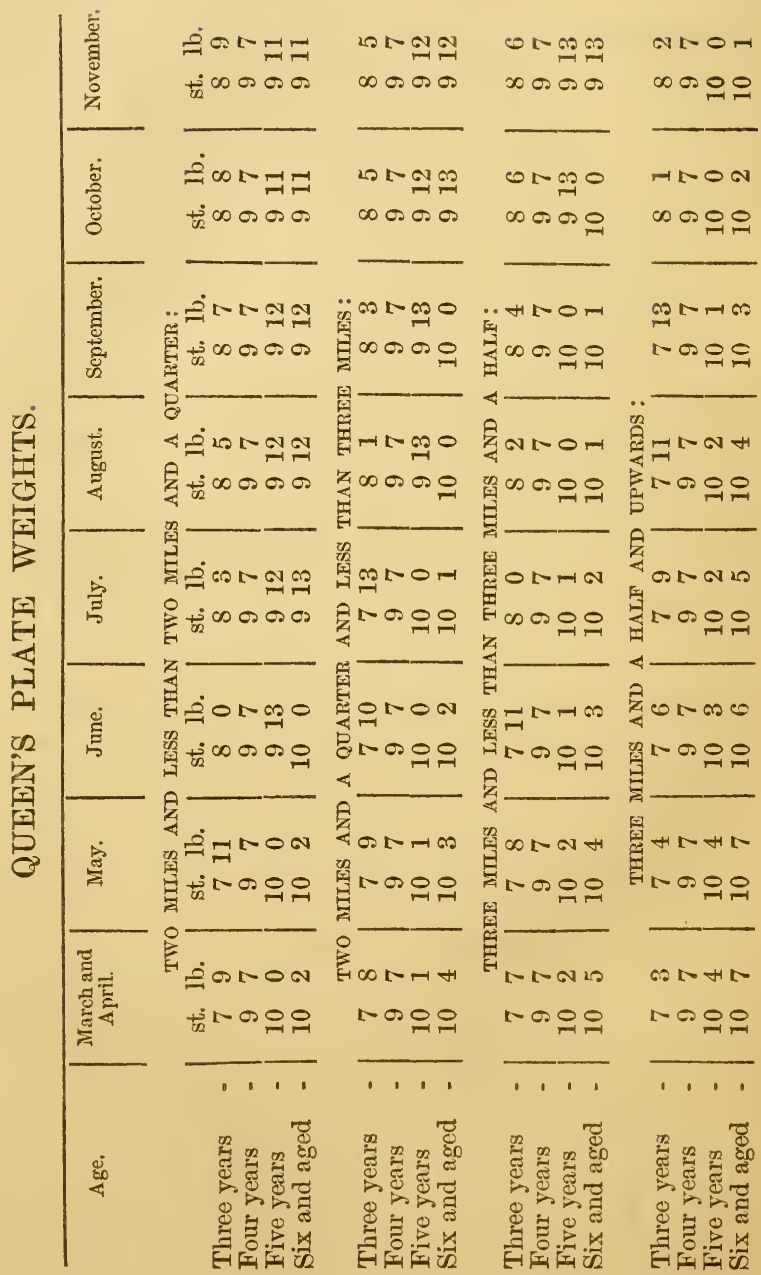




\section{FORM OF CERTIFICATE}

OF HAVING WON

\section{A QUEEN'S PLATE.}

These are to certify, that her Majesty's Plate of a Hundred Guineas was won at the day of 186 , by 's horse

called
A.B. Steward.

C.D. Clerk of the Course.

E. $\}$
* Lord Lieutenant of the County.

The Marquis of Ailesbury,

Master of the Horse to her Majesty.

[The signature of the Lord Lieutenant alone is sufficient; but that can seldom be obtained without first producing to him a certificate signed by the Steward and Clerk of the Course.]

N.B.-The certificate, when properly signed, is payable at three days' sight to the winner of the Plate (or to any other person, if endorsed by the winner) at the

* If the Lord Lieutenant be officially out of the kingdom, the signature of the Vice-Lieutenant is admissible. The certificates for the Ascot Heath Plates must be signed by the Master of her Majesty's Hounds, instead of the Lord Lieutenant. 
Office of the Clerk of her Majesty's Stables in the Royal Mews, Pimlico.

The Plates at Chester, Hampton, Goodwood, Bedford, Shrewsbury, Leicester, Liverpool, Northampton, Egham, and the 100 gs. added to the Whip at the Curragh, are given from a different fund, and the Certificates are to be addressed to the Keeper of the Privy Purse.

The Edinburgh and Caledonian Hunt Plates are paid at Edinburgh.

** The Clerk of the Stables requires the person presenting a certificate for payment to pay for a receipt stamp. 


\section{$(125)$ \\ RULES OF RACING.}

At a General Meeting of the Jockey Club, held at Newmarket on Wednesday in the Craven Meeting 1858, to receive the Report of the Committee appointed on the 4th December, 1857, to take into consideration the Rules and Orders of the Jockey Club and Rules concerning Horse-Racing in General,-the Rules, revised and newly arranged as follows, were read at length, and it was unanimously resolved that they should come into operation on Monday, April the 19th, 1858, and that all former Rules of the Jockey Club were repealed on and from that day.

The Rules concerning Horse-Racing in General govern all Meetings that are subject to the established Rules of Racing.

The Rules and Orders of the Jockey Club apply to Newmarket only.

\section{RULES CONCERNING HORSE-RACING IN GENERAL.}

1. Race-horses take their ages from the 1st of January.

2. Catch weights are, each party to appoint $\begin{gathered}\text { Catch } \\ \text { Weights. }\end{gathered}$ a person to ride without weighing. 
Feather.

3. A feather-weight shall be considered 5st. 7lb., and the usual declaration must be made when the jockey carries more than that weight.

Maiden horses.

4. A maiden horse or mare is one that has never won a plate or sweepstakes in any country.

Plates. 5. A plate is any prize given to be run for, without any stake being made by the owners of the horses to go to the winner.

6. For a plate, no person can run, either in his own name or in that of any other person, two horses of which he is wholly or in part owner, unless permitted to do so by a special clause in the conditions.

Sweepstakes. 7. Where a stake is deposited by the owners of the horses, which is to go to the winner, such race is a sweepstakes, and if an additional sum of money, cup, piece of plate, or other reward be offered to the winner, the race is still a sweepstakes, though such addition should be denominated a plate by the donor.

Three subscribers make a sweepstakes, and if a stake has the required number of subscribers at the expiration of the time of closing, and the number is afterwards reduced by death (or, in the case of a produce stake, by failure of produce), the race is not void as long as there are two horses left, 
the property of different persons, and if the number is reduced to two it is still a sweepstakes.

8. For a post match or sweepstakes each subscriber names two or more horses of the Post match or sweepproper age, but can only run one, unless a greater number is allowed by the conditions of the race.

9. When any match or sweepstakes shall be made, and no weight mentioned, the horses Omissions,
how supplied shall carry 8st. 10lbs. each, and if any weight is given the highest weight shall be 8 st. $101 \mathrm{bs}$.

10. When any match or sweepstakes shall -of Course: be made and no Course mentioned, the Course shall be that which is usually run by horses of the same age as those engaged, viz.:-

If at

Newmarket.

If yearlings, two furlongs . . Y.C.

If two yrs. old, six furlongs . T.Y.C.

If three yrs. old, one mile . . R.M.

If four yrs. old, two miles . . D.I.

If five yrs. old, or upwards, four

$$
\text { miles - . . . B.C. }
$$

And if the horses should be of different ages, the Course shall be fixed by the age of the youngest.

11. If no day is mentioned for a race it of day. shall be run on the last day of the meeting, unless otherwise agreed by all the subscribers. 


\section{As to Nominations.}

Description necessary.

When the name is sufficient.
12. In all nominations for sweepstakes and plates, the horse or mare entered must be clearly identified. The name of the sire and dam must be given, and if the dam has no name in the Racing Calendar or Stud Book, such further pedigree and description must be added as will distinguish the horse intended to be named from any other of a similar pedigree. If the dam was covered by more than one stallion, the names of all of them must be mentioned.

13. If a horse has once been entered with his name and pedigree in a race published in the 'Racing Calendar,' it will be sufficient afterwards to mention him by his name only, even though he has never started; and in entering a horse for the first time by his name in several races closing at the same time, it will be sufficient to give his pedigree in one of these nominations, and his name only in the others.

If the name of a horse which has run be changed, it is necessary, on entering the said horse, to give his old as well as his new name in every nomination until the change has been duly registered in the Book Calendar; and if his name be changed again, all his names must be repeated for the like period: but if a horse's name be changed before he has run in 
public, it shall be sufficient to give his new name in the first entry made after such change.

14. In naming for a race in which horses of different ages are admitted, the age of the When the age must be mentioned. horse named must be mentioned.

No yearlings can run for public stakes, and no horse which has run for a yearling stake is qualified to run afterwards at any place where these rules are in force.

15. No horse foaled out of the United Kingdom shall run for any race until his of foreign owner has produced a certificate of some racing club of the country where the horse was foaled, or from the mayor or other public officer of the district, stating the age, pedigree, and colour of the horse, and the marks by which it is distinguished.

16. If any horse, \&c., shall be named or entered without being identified as before directed, he shall not be allowed to start in Incorrect or insufficient description a disqualiticathe race, but his owner shall be liable to pay the forfeit, or, if a play or pay race, the whole stake.

17. If a horse should fraudulently run, or be entered to run, for any race by a false description, such horse is thenceforth disqualiFraudulent entry a perpetual dis. qualification fied for running in any race; and the owner shall be compelled to return any sum of money won in plates, matches, or sweepstakes tion. 
(whether handicap or not) which the said horse may have won.

When a horse has been struck out of an engagement by the person legally entitled to do so, if the horse be permitted to start ly mistake for the said engagement, he shall not be entitled to receive the prize though he come in first, and if he have been allowed to start in consequence of fraud or misrepresentation on the part of the owner or other person having charge of the horse, that person shall be warned off Newmarket Heath, and the horse shall be disqualified from running for any public race thereafter.

Qualitication dates from time of closing.

18. In naming or entering for any race where there shall be any particular conditions required as a qualification to start, it shall be sufficient if the horse were qualified at the expiration of the time allowed for naming or entering, and he shall not be disqualified by anything which may happen after the expiration of that time, unless so specified in the article; or unless he becomes disqualified under the rules relating to defaulters.

If a brood mare engaged in a produce stake drops her foal before the 1st of January, the nomination is void, and if she has a dead foal, or is barren, the nomination is void.

Nominations not to be

19. No person who has once subscribed to changed after closing. 
and no nomination shall be altered in any respect after the time of closing, without the consent of all the parties in the race.

20. When a person takes a nomination for a stake in which the forfeit is to be declared Exception to preceding by a particular time, and does not declare forfeit by the time fixed in the article, he shall thenceforth be considered to have taken the engagement on himself, and his name shall be substituted for that of the original subscriber.

21. When any person enters a horse, or subscribes to a stake under a fictitious name, Use of fictior in the name of a person not fully identified at the time, he shall be considered in all respects as the owner of the horse, and as the subscriber to the stake; and in the event of the forfeit not being paid, his real name shall be published in the Forfeit List.

Every person who wishes not to engage his horses in his own name, must adopt some one name, which must be registered at Messrs. Weatherby's office, and he cannot enter in any other until the change is duly notified to them; and the change shall be noticed in the first Sheet Calendar published after the receipt of such notification by Messrs. Weatherby. No person who enters hor'ses in an assumed name shall be allowed to adopt and register as such the same name as that of any gentleman who runs his horses in his own name.

A fee of 1 sov. is to be paid on each regis- 
tration, which shall be carried to the credit of the Bentinck Benevolent Fund.

Nominations not required to be made on Sunday,
Void by dexth.

Allowances to produce of untried horses or mares.
22. When the day fixed for the closing or naming for any stake, or for declaring forfeit or produce, shall fall on Sunday, subscriptions, nominations, or declarations for such stake may be received on the following day, provided that there is an interval of one clear day between the day of closing, naming, or declaring, and the day of running.

In case the day fixed for naming for any stake for which nominations are received by Messrs. Weatherby, shall fall during a Newmarket race week, nominations may be made to them there, whether so expressed in the advertisement of the stakes or not.

23. All nominations are void by the death of the subscriber.

24. In every sweepstakes in which there shall be an allowance of weight to the produce of untried horses or mares, it shall extend to horses or mares whose produce never won a registered prize in any country, but sach allowance shall be claimed by the subscriber before the expiration of the time of naming; and if not so claimed, no allowance shall be made. 


\section{Respecting Stakes and Forfeits.}

25. All stakes shall be made before starting, in cash, bank-bills, or bankers' notes,

Stakes to be paid before payable on demand, and be paid into the hands starting; of the person appointed by the Stewards to receive the same; and in default thereof by any person, he shall pay the whole stake as a loser, whether his horse came in first or not, unless such person shall have previously obtained the consent of the party or parties with whom he is engaged to his not staking.

When any person has more than one nomination in a stake, he shall not be allowed to and forfeit in certain cases. start any horse for it unless the forfeits be paid for every horse which does not start, belonging to him, or standing in his name, or in the same name as the horse which runs, as well as the stakes for those which do.

26. No person shall start a horse for any race, either in his own name or in that of any other person, unless both the owner and namer Arrears of owner and namer to be paid before starting. of such horse shall have paid all former stakes and forfeits. And this rulo shall extend to forfeits due elsewhere than at the place of running, provided a notice of such forfeits being due shall have been published in the Forfeit List, or have been delivered to the Stakeholder or Clerk of the Course by ten o'clock in the evening preceding the day of running. 
Arrears due for a horse to be paid lefore he can start.

These rules extend to Irelund.
To be pub lished in Racing Calendar.
By whom Lists of Forfeits are to be sent for pulb. lication.
27. No horse shall start for any race unless all former stakes and forfeits due for that horse shall be paid before starting, provided notice has been given as above.

28. These rules, relative to arrears of stakes and forfeits, extend to forfeits due at The Curragh and other established Meetings in Ireland.

\section{The Forfeit List.}

29. A list of unpaid forfeits, with the name of the subscriber to the stake, and the name or description of the horse, with the name or sufficient description of the stake, and the amount of the forfeit, shall be advertised in the Sheet Racing Calendar after the Newmarket July and Houghton Meetings every year.

30. The person appointed to receive stakes is to send to Messrs. Weatherby a list of unpaid forfeits, as soon after the race as conveniently may be, in order that the same may be placed upon the Forfeit List; and if he shall omit to make such last-mentioned return within a reasonable time, it may be made by the respective winners of the races for which the forfeits are due. These returns in all cases to be made in writing, and signed by the parties making them. 
31. No person whose name shall appear in the published Forfeit List shall be entitled to enter or run a horse for any plate, sweepstakes, or subscription, either in his own name or in the name of any other person, until he shall have paid up all the forfeits in respect of which his name appears in the list.

32. No horse which appears in the published Forfeit List shall be qualified to be entered or to be run for any race whatever until the forfeits mentioned in the said list as due for such horse shall have been paid.

33. In order to prevent persons who are defaulters from evading these laws, and conSuspected nominations may be tinuing to engage horses by the use of fictitious struck out. names, the Stewards shall have the power of calling upon a nominator to produce satisfactory testimony that the horse named is not the property, either wholly or in part, of any person whose name appears in the advertised list of defaulters, and if the nominator shall fail to do so, the Stewards may cause the nomination to be erased.

34 . When a horse is sold with his engagements, or any part of them, the seller has not the power of striking the horse out of the engagements of horses engagements with which he is sold; but as the original subscriber remains liable to the respective winners for the amount of the forfeits in each of these engagements, he may,

Persons appearing in Forfeit List not entitled to enter.

Horses appearing in Forfeit List not qualified to be entered. sold. 
if compelled to pay them by the purchaser's default, place the forfeit on the Forfeit List in the usual manner, as due from the purchaser to himself ; and until this forfeit is repaid, both the purchaser and the horse remain under the same disabilities as if the purchaser had been tho original subscriber.

In all cases of sale by private treaty, the written acknowledgment of both parties that the horse was sold with the engagement is necessary to entitle either buyer or seller to the benefit of this rule; but when the horse is sold by public auction, the advertised conditions of the sale are sufficient evidence, and if he has been claimed as the winner of a race of which it was a condition that the winner was to be sold with his engagements, this also is sufficient.

35. When a person has a horse engaged in the name of another person, and is entitled by purchase or otherwise to start the horse for such engagement, but is prevented by any of the preceding laws from starting his horse without previously paying up forfeits to which he is not otherwise liable, he may, if he pays these forfeits, start his horse and have the forfeits, with the names of the horses for which they are due, placed on the Forfeit List in the usual manner as due to himself. 


\section{Weighing.}

36. The name of every horse intended to start must be notified to the Clerk of the Scales, and his number be exhibited one quarter of an hour before the race, and if any alteration be made in the numbers after they have bcen exhibited, the Stewards may call upon the owner or trainer, or jockey, for an explanation. If this is not satisfactory, the owner or trainer may be fined, at the discretion of the Stewards, in any sum not exceeding 50l., and the horse shall not be allowed to start, nor the jockey to ride again, until the fine is paid.

37. Jockeys are required to weigh at the usual place of weighing, before the race, under To weigh before and
after the race a penalty not exceeding $10 \mathrm{l}$., unless excused by the Stewards for some special reason, when the fact must be notified to the Clerk of the Scales; and every rider is, immediately after the race, to ride his horse to the usual place of weighing, then and there to alight, and not before, and to weigh to the satisfaction of the person appointed for that purpose; and if a jockey riding a beaten horse does not return to weigh, he shall be fined a sum of money not less than $10 l$. or exceeding $25 l$, and if it can be proved that the owner or trainer connived at this violation of the law, they shall be fined 25l. each, and the horse shall be 
disqualified to run in public until all the fines are paid.

If the jockey dismounts before the proper time, or is short of weight, his horse is disqualified, unless he be disabled by an accident to himself or horse which should render him incapable of riding back, when he may walk or be carried to the scale.

It is optional for the jockey to weigh with his bridle, and the Clerk of the Scales will allow $11 \mathrm{~b}$. for a curb or double bridle, but no weight is allowed for a snaffle bridle unless it is put into the scale before the horse is led away, and no whip or substitute for a whip shall be allowed in the scales.

Over-weight. 38. Each jockey shall be allowed 2 lb. above the weight specified for his horse to carry, and no more, unless a declaration has been mado to the Clerk of the Scales of the extra weight the jockey is about to carry one half an hour before the time fixed for the said race, and the extra weight shall be appended to the horse's number when it is put up. In default of such declaration the horse carrying more than $2 \mathrm{lb}$. over his specified weight shall be placed as the last horse in the race, the jockey shall be fined $5 l$. for his neglect, and shall not be allowed to ride until the said fine be paid; and the weight each horse actually carried, if more than $2 \mathrm{lb}$. above his weight, shall be 
published in the first list printed after the race, and also in the Racing Calendar.

39. In all handicaps with twenty subscribers, when the highest weight accepting Raising weights in is under $8 \mathrm{st} .12 \mathrm{lb}$, it is to be raised to that weight, and the others in proportion; but in all minor handicaps and in two years old handicaps, when the highest weight accepting is under $8 \mathrm{st.} 10 \mathrm{lb}$., it is to be raised to 8 st. $10 \mathrm{lb}$, and the others in proportion.

40. No horse shall carry less than 5 st. $7 \mathrm{lb}$. for any race, and horses which have run in than 5si. $71 \mathrm{~b}$. violation of this Rule shall not be allowed to run at any place where these Rules are in force.

\section{Starting.}

41. When the riders of the horses brought out to run for any race are called upon by the person appointed to start them to take Horses going to the post to be considered starters. their places for that purpose, every horse which comes up to the post shall be liable to his whole stake.

42. The starter has authority to order the jockeys to draw up in a line as far behind the Power of the starter. Starting-post as he may think necessary, and any jockey disobeying the orders of the starter, or taking any unfair advantage, shall be punished by fine or suspension, according to the nature and degree of his offence, at the discretion of the Stewards. 
No jockey can be suspended beyond the meeting at which the offence is committed, unless the case has been heard by the three Stewards of the Jockey Club, and in the absence of any of the Stewards, a Member or Members of the Jockey Club shall be deputed to act for the Steward or Stewards absent.

The punishment inflicted shall not be declared till after the last race of the day on which it is awarded.

A sentence duly passed upon a jockey cannot be remitted by the Stewards without the authority of a General Meeting of the Jockey Club.

The starter is prohibited from making a running start-the horses must walk up, and be started from a walk, and if the Starter from negligence or inattention allows a start to take place on the wrong side of the Starting-post, he shall be fined a sum of money not exceeding $50 l$., and the start shall be declared null and void.

Foul riding.

43. If in running for any race one horse shall jostle or cross another, such horse is disqualified for winning the race, whether such jostle or cross happened by the swerving of horse, or by the foul and careless riding of the jockey or otherwise ; and where one horse crosses the track of another, it is deemed a disqualification, unless he be two clear lengths, or more, before the horse whose track he 


\section{Rules of Racing.}

crosses. And if such cross or jostle shall be proved to have happened through the foul riding of the jockey, he shall be subject to such punishment as the Stewards may think fit to inflict.

44. Horses running on the wrong side of a post and not turning back are disqualified.

\section{Second Horse.}

45. When it is a condition of a stake or plate that the owner of the second horse shall Money for second horse. receive a certicin sum of money out of the stakes, or out of the plate, and the race is walked over for, or no second horse is placed, the winning horse is entitled to the whole prize. If the money advertised to be given to the second horse is a separate donation from the Race-fund or other source, and the race is walked over for, or no second horse is placed, the money is not given at all.

When the entrance money for a plate is advertised to be given to the owner of the second horse, and the plate is walked over for, or no second horse is placed, the entrance money is to be returned.

\section{Dead Heats.}

46. If for any plate or sweepstakes, not to be run in heats, the first two or more horses When to be run over shall come in so near together that the Judge again. 
shall not be able to decide which won, those horses shall run for such prize over again, after the last race on the same day; the other horses which started are deemed losers, and are entitled to their respective places, as if the race had been finally determined the first time.

Effect of dividing after a dead heat.

Dead heat for second place.
47. When horses run a dead heat for a sweepstakes or plate, and the parties agree to divide the stakes, such horses shall be liable to carry extra weight as winners of that race, and if there is any money for the second horse they divide that also.

48. When horses run a dead heat for the second place they divide any money that may be payable to the second horse, and if there is any money for the third, they divide that also; and if any of these horses run for a race in which there is a penalty for having received a certain amount of money as second horse, they shall be considered as having received only the amount of their respective shares.

\section{Heats.}

49. When a race is run in heats, a horse, to win the prize, must be the actual winner of two heats, unless no horse appear against him, when one walk over is sufficient.

50. In running of heats, if it cannot be do- 
cided which horse is first, the heat goes for nothing, and they may all start again, except it be between two horses that had each won a heat.

51. When tro horses have each won a heat, they only must start for a third, and the preference between them will be determined by it.

52. When a plate is won by two heats, the preference of the horses is determined by the places they get in the sicond heat.

53. Horses drawn before the plate is won are distanced.

54. No distance in the third heat.

55. No person shall start more than one horse of which he is the owner, either wholly or in part, and either in his own name or that of any other person, for any race for which heats are run.

\section{Selling Races.}

56. When it is made a condition of any plate or sweepstakes that the winner shall be How the winner is to sold for any given sum, the owner of the second horse being first entitled, \&c., no other person than one who ran a horse in the race shall be entitled to claim. The claim must be made to the Judge, the Clerk of the Scales, the Clerk of the Course, or one of the Stewards 
present, within a quarter of an hour after the race. The horse claimed shall not be delivered till he is paid for; and he must be paid for by ten o'clock at night on the day of the race, otherwise the party claiming shall not be entitled to demand the horse at any future period; but, nevertheless, the owner of the winning horse may insist upon the claimant taking and paying for the horse claimed.

Sales by auction.

57. When it is a condition of a selling race that the winner shall be put up to auction after the race, the half of any surplus which may thereby be obtained over and above the price for which the horse was entered to be sold shall be paid to the owner of the second horse, and this shall not invalidate the privilege of the second horse as to the prior claim of any beaten horse under Rule 58. If at any country meetings the winner of a selling race shall by the terms prescribed bo sold by auction, and the moiety of the surplus be not paid to the orwer of the second horse, the paid winner shall be disqualified for being entered or for running in any race where the Newmarket rules of racing are in force.

Claim of 58. Any horse running for a selling stake beaten horses. or plate is liable to be claimed by the owner of any other horse in the race for the price for which he is entered to be sold, and the amount of the stake-the owner of the second 
horse to be first entitled to claim, and the others in the order in which their horses are placed, and the winner to have the last claim.

Horses running for a race which is excepted by special conditions from the operation of this rule, are not qualified to be entered for a handicap at any meeting professed to be subject to the established rules of racing.

59. No person can claim more than one horse in the same race.

60. If two or more persons equally entitled wish to claim, they shall draw lots for the priority.

\section{Extra Weight and Allowances.}

61. When it is a condition of any race that horses shall carry extra weight for winning a certain number of prizes during the year, or be allowed weight for having been beaten a certain number of times during the year, such winnings and losings shall date from the 1st of January preceding, and shall extend to the time of starting, unless otherwise specified.

62. Extra weights and allowances are not accumulative, unless so specified in the conditions.

63. Horses do not carry extra weight for winning a match, and are not entitled to Not accumulative. allowance for having been beaten in a match. hurdle races. 
Winners of hurdle races are not considered winners in flat racing.

64. A horse walking over or receiving forfeit, except for a match, is deemed a winner.

Value of prizes, how calculated.
Examination of mouth.

65 . In estimating the value of any prize no deduction shall be made, except of the winner's own stake and of any sum or sums required by the conditions to be paid out of the stakes to the owners of any other horse or horses in the race-the entrance for a plate not to be deducted. And every prize, not in specie, shall be estimated at its advertised value in sovereigns, and if such value is not designated, it shall be taken at the cost price.

The winner of the Queen's Tase at Ascot is exempt from any penalty for such winning, unless this prize is specially mentioned in the conditions of the race.

\section{Objections io Qualification.}

66. Wher the age or qualification of a horse is objected to, either before or after running for any race, the Stewards, or those whom they may appoint, shall have power to order an examination of the horse's mouth by competent persons, and to call for all such evidence as they may require, and their decision shall be final, unless they shall sanction the removal of the question in dispute into a Court of Law. 
Any person requiring a horse's mouth to be examined must pay the expense of such examination, unless the horse is proved to be of the wrong age, in which case such expense shall be paid by the owner of the said horse.

67. All complaints of foul riding, or of horses not running the proper Course, or of When complaints must any other irregularities occurring in the race, must be made either by the owner, jockey, or groom of the horse, to one of the Stewards, to the Judge of the race, to the Clerk of the Course, or the Clerk of the Scales, within a quarter of an hour after the race.

As it is expedient that there should be a statute of limitations with respect to the time of lodging objections against winning horses, no complaints can be entertained after the conclusion of the Race Meeting, save and except charges of fraudulent entry, or of running horses under a false description, which may be investigated at any period within one year from. the date of the offence.

68. When the qualification of any horse is objected to by ten o'clock in the morning of the day of starting, the owner must produce a Objections to qualification: -when to be made. certificate, or other proper document, to the Steward or Clerk of the Course, or to the Keeper of the Match-book if the case happen at Nerrmarket, before the race is run, to prove the qualification of the horse; and if he shall 
start his horse without so doing, the prize shall be withheld for a period to be fixed upon by the Stewards, at the expiration of which time, if the qualification be not proved to the satisfaction of the Stewards, he shall not be entitled to the prize, though his horse shall have come in first, but it shall be given to the owner of the second horse. When the qualification of a horse is objected to after that time, the person making the objection must prove the disqualification. 


\section{R ULES A N D OR D ERS OF THE JOCKEY CLUB.}

Respecting the Stewards.

1. The three Stewards of the Jockey Club shall be continued in their office till the next Mode of annual election.

annual financial meeting (which takes place in the Craven), when the senior Steward shall vacate after settling the accounts made up to the 31st of December preceding, and shall then name a member of the Jockey Club to succeed him, subject to the approbation of the members of the Jockey Club then present, and at every subsequent financial meeting the senior Steward shall, in like manner, retire and propose his successor.

2. If any of the Stewards shall die or resign, the remaining Stewards may appoint a memIn case of death or ber of the Club to succeed the deceased or declining Steward, but such nomination shall be notified to the Club at the first general meeting, and if the appointment meets their approval, the said member shall remain in office until the expiration of his predecessor's time. 
Substitute for absent Stewards.

The Stewards have power - to appoint officers :

to fix time of starting:

to manage the Course and Exercise ground :

to postpone races :
3. When only one Steward is present, and neither of the absent Stewards shall have appointed a substitute, the member of the Jockey Club present who has last served the office shall act ex officio.

4. The three Stewards shall have the power of appointing all the public officers and the servants of the Club; the Keeper of the Match-book to receive the stakes and collect the entrance-money, and all other funds belonging to the Jockey Club ; and the Stewards shall produce an account of the funds and disbursements of the Club at the annual financial meeting, and they shall be responsible to the Club for the correctness of the annual accounts, and for all the money collected as belonging to the Jockey Club.

5. The Stewards shall fix the hour of starting for each race at or before nine o'clock in the evening preceding the day of running, and notice of the time of starting is to be fixed up in the Coffee-room immediately afterwards.

6. The Stewards have full power to make such regulations as they may think proper in regard to the Course and Exercising-ground.

7. The Stewards of the Jockey Club have the power, in cases of urgent necessity, of putting off the races from day to day until a Sunday intervenes. 
8. All disputes relating to racing at Newmarket shall be determined by the three to settle disputes at

Stewards; if only two Stewards be present they shall fix upon a third person, being a member of the Club, in lieu of the absent Steward, but the Stewards, if they think fit, may call in any other members of the Jockey Club to their assistance, or may refer the case to a general meeting, if the importance or difficulty of the matter in dispute shall appear to them to require it. The witnesses examined shall be required to sign their evidence, and if either party desires to have a shorthand writer engaged to take down the evidence, the Stewards may (if they think proper) engage a writer at the expense of the person making the request.

9. If any dispute arising elsewhere shall be referred to the Stewards of the Jockey Club, and they shall think fit to take it into consideration, the matter must relate to horseracing, and be sent by the Stewards of the MIeeting where the matter in question occurred.

10. The Jockey Club and the Stewards thereof take no cognizance of any disputes or claims with respect to bets.

11. The Stewards have a discretionary power to warn any person off the Race-course at mas decids: cases referred to them from other places:

Newmarket, or any premises belonging to the Jockey Club, and in case of such notice being

may warn off the Course:

not to decide betting cases: the course: 
disregarded, to take legal proceedings against the offenders.

12. If a member of the Jockey Club shall impugn or object to any act or decision of the Stewards, he shall give notice of it in writing to the Keeper of the Match-book, who will immediately request the Stewards to fix an early day to assemble the members for the purpose of hearing the objection.

act at Epsom and Ascot.
13. The Stewards of the Jockey Club are, ex officio, Stewards of Epsom and Ascot.

\section{Respecting the Admission of New Members.}

For the Juckey Club.

14. Ballots for the Jockey Club may take place in any of the Newmarket Meetings. A candidate must be proposed and seconded by two members in a meeting previous to the ballot, or in case the ballot takes place in the Craven Mceting, notice of his being a candidate shall be given in the 'Sheet Calendar' published next preceding that meeting, and also put up in the Coffee-room on the Monday in that meeting; and notice to be given in writing, and put up in the Coffee-room, on what day the ballot will take place, at least one day before the time of balloting. Nine members (at the least) shall ballot, and two black balls shall exclude.

Members of the Jockey Club being abroad 
for two or more whole years from the 1st of January, shall not be liable for their subscription during their absence.

15. The ballots for members of the Nerw Rooms may be in any of the six established For the New Meetings at Newmarket. Each candidate must be proposed by a Member of the Jockey Club, and his Christian and Surname, and usual place of abode, with the name of the Member proposing him, put up in the Dining and Card-rooms at Newmarket (or in such other place as the Stewards shall appoint) on the day preceding the ballot. The ballot shall be in the morning, between the hours of eleven and one; or in the afternoon, between the hours of four and six. Members of the Jockey Club only shall be allowed to ballot. Nine Members (at least) shall ballot, and two black balls shall exclude. If eighteen members ballot, there must be three black balls to exclude.

16. A Member of the Jockey Club may be admitted a Member of the New Rooms without ballot, by applying to Mr. Weatherby, Keeper of the Match-book, and paying the same sum for his admission, and the same subscription, as are required of Members chosen by ballot.

17. The ballot for Members of the Coffeeroom shall be in the Coffee-room at NewFor the Coffee-room. market (or at such other place as the Stewards shall appoint) on any day in the present six 
established Meetings, between the hours of eleven and one o'clock in the morning. Each candidate must be proposed by a Member of the Jockey Club, and his Christian and Surname, and usual place of abode, with the name of the Member proposing him, be put up in the Coffee-room the day before the ballot. Members of the Jockey Club only can ballot. Nine Members (at least) must ballot, and two black balls shall exciude.

18. A person, though chosen, shall not be considered as a Member of any of these Clubs until he shall have paid the usual sums for the admission and subscription of a new Member. And the name of every Member whose subscription shall be in arrear for one year shall be placed over the Chimney-piece in the New Rooms and in the Coffee-room at Newmarket, in the Craven Meeting in each year. And if such arrear be not paid at the end of the following Spring Meeting, he shall cease to be a Member, and shall not be again admitted as a member until his arrears be paid, and until he be again chosen by ballot.

19. The subscription to the New Rooms and Coffee-room, and all other charges, except the subscription to the Jockey Club, are paid half-yearly ; the July Meeting to be included in either half-year. 
20. Any Member of the Juckey Club (not being a Member of the New livoms) may be admitted to the New Rooms and Coffee-room for any one meeting, by applying to MIr. Weatherby, Keeper of the Match-book, without any other charge than the payment of two pounds. In the event of such person attending any other meeting in the course of the same year, he is to be considered as a Member of the New Rooms, and liable to all the usual charges.

21. If any foreigner should be proposed at any time as a candidate for the new Rooms or Coffee-room, an immediate ballot may take place for such election, and all foreigners who are elected are liable only to the household expenses.

22. Gentlemen not Members of the New Rooms or Coffee-room may be admitted to the Stands on Newmarket Heath on payment of a life subscription of ten pounds, provided that they are elected by ballot in the same manner as Members of the Coffee-room, and that the number so admitted shall not exceed fifty.

\section{Trials.}

23. The day, with respect to the engaging of the ground for trials, shall be divided into three periods: that is, previously to eight
Temporary admission of non-Members.

Election of foreigners.

Admission to the Stands.
How to engage the ground. 
o'clock in the morning, from one to half-past three in the afternoon, and after half-past three in the afternoon, from the first day of the Craven Meeting to the end of the Houghton Meeting: during the rest of the year the first period extends to nine o'clock in the morning. No trainer shall have the ground for trying horses more than one morning and one portion of the afternoon in the same week, and trainers having less than ten horses shall be allowed to have the ground only for one period of time. A trainer not having more than five horses in training can only lave his name down once at the same time; a trainer not having more than ten horses only twice; and a trainer with more than ten only three times.

Notice for engaging the ground shall, at least one day before the day it is used, be entered in a book to be kept for that purpose at the Keeper of the Match-book's Office in Newmarket. And no notice or warning shall be deemed sufficient unless given as before directed.

If any person shall be detected in watching a trial, or shall be proved to have employed any person to watch a trial, he shall be served with a notice to keep off the heath; and if in the employment of any Member of the Club or of any groom or rider employed by any Member of the Club, he shall be dismissed from his service, and not again employed. 


\section{The Cup and Whip.}

24. The Cup may be challenged for on the The Cup. Tuesday or Wednesday in the July Meeting in each year, to be run for over the B. C. on Thursday in the Houghton Meeting following, by horses, \&c., the property of Members of the Jockey Club or of the Rooms at Newmarket; four years old carrying 8 st. $7 \mathrm{lbs}$, five years old, 9 st. 1 lb., six years old and aged, 9 st. $4 \mathrm{lb}$. Each person, at the time of challenging, is to subscribe his name to a paper to be hung up in the Coffee-room at Nerrmarket, and deliver to the Keeper of the IIatch-book the name or description of the horse, \&c., sealed up, which shall be kept till six o'clock on the Saturday evening of that week; and if not accepted, or only one challenger, to be returned unopened: but if accepted, or if more than one challenger, to be then opened and declared a match, or sweepstakes of 200 sov. each, play or pay. If the challenge be not accepted, the Cup to be delivered to the Keeper of the Match-book in the IIeeting ensuing the challenge, for the person who may become entitled to the same.

25. The Whip may be challenged for twice The Whip. in each year, viz.: on the Tuesday after the July Meeting, when the acceptance must be signified or the Whip resigned on the Tuesday following, or challenged for on Monday 
or Tuesday in the Second October Meeting, when the acceptance must be signified, or the Whip resigned, before the end of the same meeting. If challenged for and accepted in July, to be run for on the Tuesday in the Second October Meeting following; and if in the October, on the Thursday in the First Spring Meeting following; B.C. weight 10 st., and to stake 200 sov. each, play or pay.

\section{Charges at Newmar:ket.}

Discount on Forfeits.

26. Five pounds per cent. shall be allowed on all forfeits under $100 l$. and not less than 20l. declared to the Keeper of the Matchbook, at or before ten o'clock the evening before running; and if the forfeit amount to $100 l$. and upwards, $10 l$. per cent. shall be allowed. All forfeits shall be paid before twelve o'clock at night of the day fixed for the race, and on those forfeits which shall not be so paid, the deduction for the timely declaration of such forfeit shall not be allowed.

No horse shall be considered as struck out of his engagement, unless the owner, or some person authorized by him, shall give notice to the Keeper of the Match-book, or to his Clerk, or to one of the Stewards present.

One per cent. 27. The Stake-holder shall deduct 1l. per Plates. cent. upon all sums won at Newmarket in sweepstakes or matches, where the clear sum 
to be received by the winner, over and above his own stake, shall amount to $100 l$. or more (unless the winner shall object to allowing such deductions to be made), and the money so raised shall be disposed of in the following manner-viz.

Two handicap plates of $100 l$. each, for three, four, five, six years old, and aged horses, shall be annually given to be rin for ; one in the Second October Meeting, A.F., and the other in the Houghton Meeting, from the D.I. And if any horse-keeper shall object to contributs to the above fund, he will not be allowed to start a horse for either of those plates.

28. The Stake-holder at Newmarket is allowed to retain, out of the stakes in his The Stakeholder. hands, the following fees for his trouble -viz.

For every match, one pound.

For every plate, one pound.

For every subscription or sweepstakes, where the whole stake exceedis $100 l$. and does not amount to $1,000 l$., two poands.

For every sweepstakes where the whole stake amounts to $1,000 l$. or upwards, five poinds.

[The charges for stake-holding at Ascot and Goodwood are the same as at Newmarket, with the exception of handicaps, for which the charge is one per cent.] 
Fees for nominations.

Weighing Fees.

Heath tax.
29. The Keeper of the Mratch-book is entitled to charge a fee of $2 s .6 \mathrm{~d}$. on all nominations at Newmarket, if published in the Racing Calendar before running, but not on the entries which are made at Newmarket during the week of running.

30. The weighing fee for plates and stakes is $10 s$. each horse, and 10s. extra for the winner; the former is to be paid to the Keeper of the Match-book at the same time with the stakes, and for plates at the time of entry.

The Keeper of the Match-book shall charge the proprietors of such horses as receive forfeit, and shall be excused from appearing, with the same fees for weights and scales as if they had come over the Course.

No weighing fee is charged for matches.

31. Towards defraying the expense of repairing the Course and Exercise-ground, two guineas annually shall be paid in respect of every horse that shall be trained at Newmarket, and one guinea annually for every horse that goes there for any race-meeting and uses the ground for exercise, or runs any private trial or public race thereon. And the same shall be paid by the stable-keeper or servant having the care of such horse, and be charged by him to the owner of such horse. The Stewards shall make such orders as they think fit relative to the returns to be made by the 
stable-keepers or servants, of horses under their care, and if any stable-keeper or servant shall fail to make a true return according to this order, he will be surcharged one guinea for each horse omitted in his list.

N.B.-At present all trainers are required to send in on the 1st of February, a list of the horses which have been under their charge from the 1st of January, and on the 1st of every succeeding month a list of any additional horses that have been under their care since the preceding return.

32. The entrance to a plate at Newmarket Entrance to shall not exceed 3 sov. plates.

33. When a plate given from the funds of the Jockey Club is walked over for, only half Plates walked over the amount is paid.

34. The winner of the $2,000 \mathrm{gs}$. stakes shall pay 10l. to the Judge, of the Cesarewitch and Payments to the Judge.

Cambridgeshire stakes $30 l$. each, of the Derby at Epsom 50l., and of the Oaks 30l., in addition to his salary for judging other races at Epsom and Newmarket.

Relating to other matters not before specified.

35. Every groom shall have his horse at Starting. the post, ready to start, at the time appointed by the Stewards; and every jockey is to be there, ready to start at the same time. Every 
groom or jockey making default herein shall forfeit $5 l$., to be paid to the Keeper of the Match-book, and by him accounted for to the Stewards.

The person appointed to start the horses shall mark in his list the time when the horses in each race actually started; and if there have been any false starts, the first of them shall be considered as the time of starting for that race, and he shall make a report thereof to the Keeper of the Match-book in the afternoon of the day the races are run. And if any delay shall have taken place, he shall state by whom, or by what cause, the delay was occasioned. He shall regulate his watch by the Coffee-room clock, which shall be considered as the true time for this purpose.

Races for gentlemen riders.

Raising weights in bandicaps.
36. No races for gentlemen riders are allowed at Newmarket during the regular meetings without the sanction of the Stewards, and, that accorded, such races must be the first or last of the day.

37. Any member of a Racing Club riding in with the leading horses in a race shall be fined to the amount of $25 l$, and all other persons to the amount of $5 l$.

38. Rule 39, concerning Horse-Racing in general, extends at Newmarket to the highest weight left in at ten o'clock the preceding evening in handicaps for plates and stakes 


\section{Rules and Orders of the Jockey Club.}

where there is no declaration of forfeit, and where the weights are fixed the night before running.

39. If any trainer shall engage a man or boy actually serving in the stables without consent of his last employer, or shall harbour or employ any man or boy who has run away, and, after due warning having been published in the 'Racing Calendar', shall continue to retain such boy in his service, he shall not be allowed to train or run horses at Newmarket, or at other meetings where the Newmarket Rules are enforced.

Every jockey at the termination of his apprenticeship is free to form engagements for himself, irrespective of any which may have been made for him during such apprenticeship.

40. If it can be proved against any person that he has offered money before or after a race to any Judge, Starter, or Handicapper, or promised any part of the stake or prize, or any share or part of a bet, he shall be warned off the Course at Newmarket, and other places where the Jockey Club Rules are in force; and any Judge, Starter, or Handicapper who shall, before or after a race, demand or receive money of any person, shall be warned off the Course at Newmarket, and other places where the Jockey Club Rules are in force. 
41. No race can be run at Newmarket over a shorter distance than the T.Y.C., with the exception of two yrs. old plates and stakes run between the commencement of the Craven and the end of the First October Meetings, which may be run any Course not less than half a mile.

This rule not to apply to matches, or to private sweepstakes of 25 sov. each or upwards, handicap sweepstakes excepted.

42. No rule or alteration of a rule of the Jockey Club takes effect until it has been published in the 'Racing Calendar', unless specially ordered to the contrary at the time the said rule or alteration is adopted; and no new rule of the Jockey Club can be passed, and no rule be rescinded, without previous notice being given in the Sheet Racing Calendar, nor at any meeting at which less than nine members are present. 


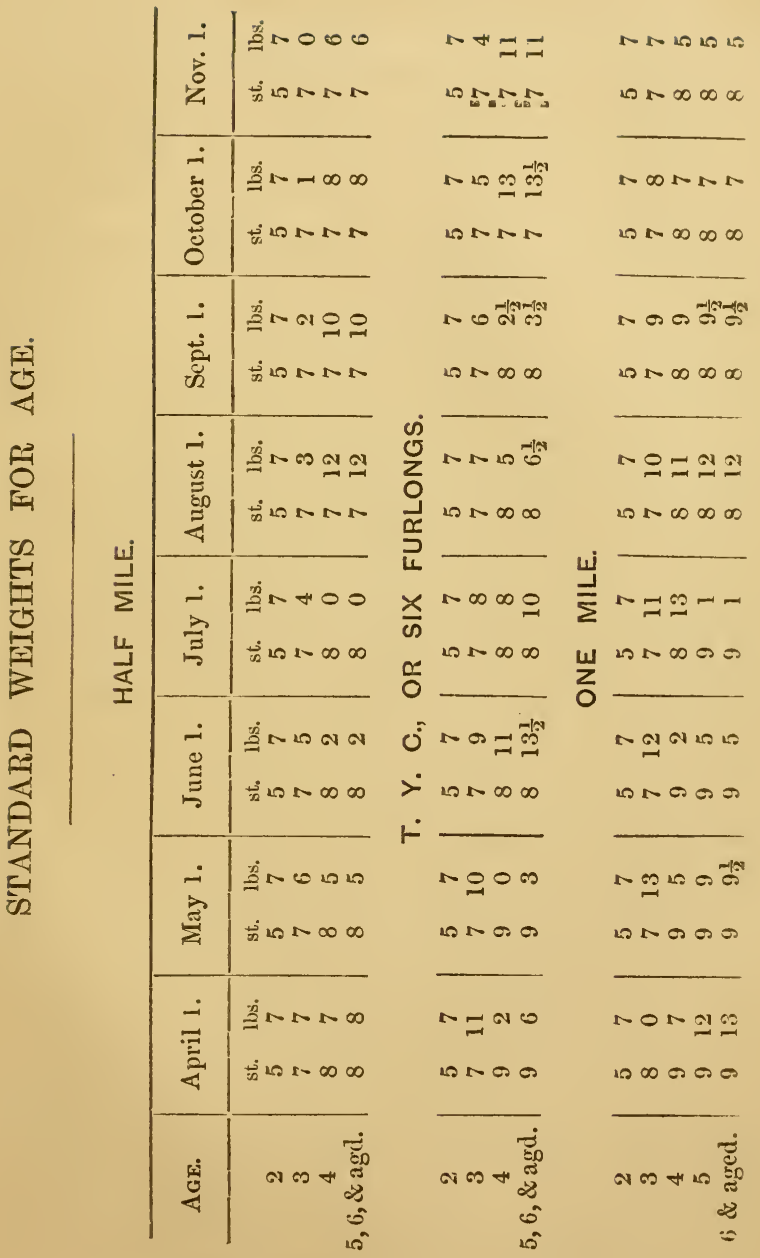




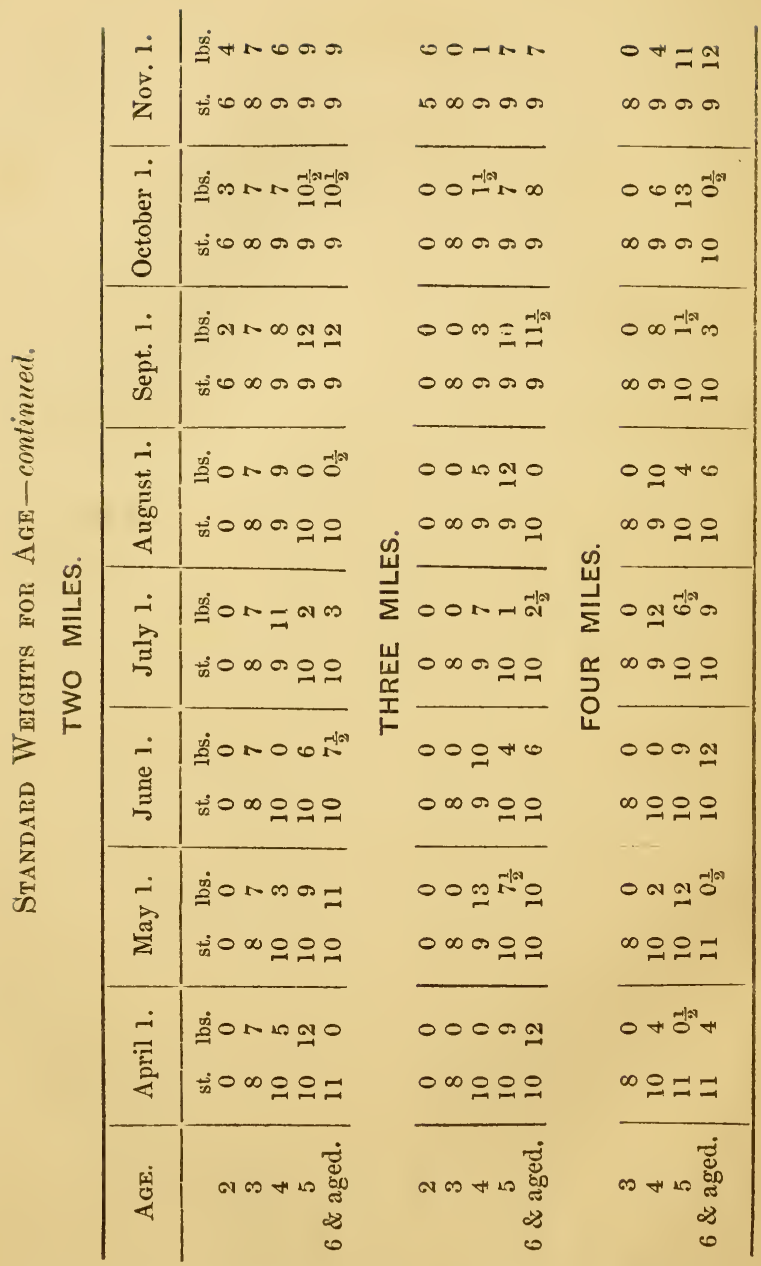

London: Printed by W. Clowes \& Soss, Stamford Street and Charing Cross. 


\section{THE SPRING EDITION (1866)}

OF

\section{BAILY'S TURF GUIDE}

CONTANING

THE NOMINATIONS FOR 1866; AND ENTRIES FOR THE GREAT STAKES OF 1867;

WITH THE HORSES INDEXED, AND THEIR PEDIGREES.

A Calendar of all Races and Steeple Chases in Great Britain, Ireland, France, Belgium, and Baden-Baden, for 1865,

\section{WITH A COMPLETE INDEX;}

COLOURS OF THE RIDERS; IENGTHS OF COURSES; SALES OF BLOOD STOCK; LAWS OF RACING; LIST OF TRAINERS, JOCKETS, ETC.

WLNNERS OF GREAT PRIZES FROM THEIR COMIMENCEMENT.

\section{Opinions of the Press.}

"I never opened a volume containing more important matter. 'Baily' is, without exception, the very best guide to the Turf, past and presert." -Morning Advertiser.

"This welcome companion is published, and fully maintains the high opinion we have so often expressed in its behalf. Baily's 'Turf Guide' is even more valuable than heretofore."-Bell's Life.

"Baily's 'Guide to the Turf' has made its appearance, and every line has been strictly revised by the proper authorities."-Morning Post.

"Mr. Baily has published his 'Scarlet Guide' in the most complete manner. The information to be found within its pages is of the most accurate character." - Birmingham Journal.

" 'Baily's Guide' is unquestionably the best worle of reference on racing that has yet been published."-Manchester Guardian.

“'Baily's Turf Guide '-this indispensable publication is issued, and is quite equal to its predecessors in excellence."-Manchester Courier.

"Mr. Baily deserves the thanks of the racing public for his valuable 'Turf Guide.' He evidently understands the wants and requirements of the racing world." - Sporting Life.

"Mr. Baily has issued his 'Turf Guide,' which is superior to 'Ruff' in its best day."-Daily Telegraph.

$$
\text { London: A. H. BAILY \& CO., Cornhill. }
$$




\section{Advertisements.}

Published Monthly, price 1s. 6d., by post 1s. Sd.,

\section{BAILY'S MAGAZINE.}

A Volume is completed every seven months, bound in cloth, price 10s. $6 \mathrm{~d}$.

The following Portraits with Mremoirs have already been published:-

\section{VOL. I.}

HON. ADMIRAL ROUS. DUKE OF BEDFORD. DUKE OF BEAUFORT. GEORGE PAYNE, Ese.

EARL OF GLASGOW. MARQUIS OF EXETER. EARL OF ZETLAND. Mr. GEORGE PARR, the Cricketer.

AND A PORTRAIT OF ALFRED DAY, the Jockey.

\section{VOL. II.}

EARL OF DERBY.

EARL OF CHESTERFIELD. JOHN GULLY, EsQ. VISCOUNT PALMERSTON, M.P.
SIR TATTON SYKES, BART. GEORGE OSBALDESTON, EsQ. JAMES MERRY, EsQ. M.P.

\section{AND A PORTRAIT OF J. WELLS, the Jockey.}

\section{VOL. III.}

SIR JOSEPH HAWLEY, BART. EARL OF STRADBROKE. DUKE OF RICHMOND. COLONEL TOWNELEY.
EARL OF PORTSMOUTH. GENERAL PEEL, M.P. GEORGE LANE FOX, EsQ.

AND A PORTRAIT OF SAM ROGERS, the Jockey.

VOL. IV.

COUNT LA GRANGE. W. G. K. GRATWICKE, EsQ. EARL SPENCER. MR. JOHN SCOTT.
MARQUIS OF AILESBURY. CAPT. JOHN WWHTE. EARL OF STAMFORD.

AND A PORTRAIT OF THOMAS ALDCROFT, the Jockey. 


\section{Advertisements.}

VOL. V.

SIR RICHARD BULKELEY, BART., CAPT. PERCY WILLIAJIS. M.P.

MARQUIS OF ANGLESEY.

EARL OF STRAFFORD.

H. VILLEBOIS, EsQ.

SIR CHARLES MONCK, BART.

SIR WATKIN WYNN, BART., M.P.

AND A PORTRAIT OF MR. GEORGE THOMPSON.

VOL. VI.

EARL OF SEFTON.

W. SELBY LOWNDES, ESQ.

HON. W. ERNEST DUNCOMBE,

M.P.

AND A PORTRAIT OF THOMAS CHALLONER, the Jockey.

EARL OF BESSBOROUGH.

LORD FITZHARDINGE.

DUKE OF RUTLAND.

RICHARD C. NAYLOR, EsQ.

VOL. VII.

VISCOUNT FALMOUTH.

LORD WILLIAM POULETT.

EARL OF WILTON.

VLSCOUNT ST. VINCENT.

C. C. GREVILLE, EsQ. SIR CHARLES SLINGSBY, BART. EARL OF WEMYSS \& MARCH.

AND A PORTRAIT OF GEORGE FORDHAJ, the Jockey.

VOL. VIII.

LORD POLTIMORE.

Mr. RICHARD TEN BROECK.

IIr. FRAYCIS POPHAMI.

Mr. TAILBY.

Mr. HENRY LOWTHER.

EARL OF WESTMORLAND.

EARL OF CRAVEN.

VOL. IX.

EARL OF UXBRIDGE.

LORD GROSVENOR.

SIR JOHN TROLLOPE, BART.

LORD HAWKE.

EARL POULETT.

CAPT. CHRISTIE.

SIR LYDSTON NEWMAN, BART.

AND A PORTRAIT OF J. GRIMSHAW, the Jockey.

\section{VOL. $X$.}

Mr. W. G. CRAVEN.

Mr. R. A. H. MITCHELL.

MARQUIS DROGHEDA.

EARL OF COVENTRY.

MR. HENRY CHAPLIN.

LORD MIDDLETON.

SIR F. JOHNSTONE, BART., AND CAPT. COVENTRY.

Each Portrait on India Paper, 2s. $6 d$.

London: A. H. BAILY \& Co., Cornhill. 


\title{
Advertisements.
}

\author{
THE
}

MON

HAVING BEEN

PAINTED AND DECORATED THROUGHOUT

DURING THE WINTER,

\section{THE MANAGER}

RESPECTFCLLY INFORMS

đIf a dobility and bentry

THAT

The Hotel is now READY for their reception. 


\section{Advertisements.}

1Sth Annual Edition. Price 2s. 6d.; by post, 2s. $8 d$.
$\mathrm{W}^{\mathrm{H}} \mathrm{O}^{\prime} \mathrm{S}$
$\mathrm{W} \mathrm{H} \mathrm{O}$ for
1866 .

The following, taken from the List of Contents, will afford some idea of the mass of Classified Information this handsome little Annual so readily furnishes :-

TEMBERS OF THE NEW HOUSE OF COMMONS

1 (Their Age, Constituency, and Politics).

THE NEW PREMIER, and reconstructed CABINET.

ๆHE ROYAL FAMILY, ITS MEMBERS, AND BRANCHES.

IHE NOBILITY, their Rank, Name, Ages, and Heirs.

UR BARONETS, their Age, Creation, and Successors.

THE JUDGES of ENGLAND, SCOTLAND, and IRE1 LAND.

$H^{\text {OIIE and COLONIAL BISHOPS. }}$

FNGLISH AND FOREIGN AMBASSADORS.

OFFICERS OF THE ARII, and Date of Service.

UR ADMIRALS, their Rank, Flag, and Service.

$Q^{\text {UEEN'S COUNSEL, and County Court Judges. }}$

EANS and ARCHDEACONS-Appointment and Univer-
sity. THE LONDON CLUBS, their. Situation, and Secretaries.

$\mathrm{O}^{\mathrm{UR}}$ LOSSES by DEATH in 1865 .

London: A. H. BAILY \& CO., CoRnHLL. 


\title{
Advertisements.
}

\section{SPORTING CELEBRITIES.}

\author{
PORTRAITS
}

OF

\section{EMINENT SPORTSMEN}

\section{MASTERS OF FOXHOUNDS.}

(From 'Baily's Magazine.')

Each Proof on India Paper. Price 2s. 6d.

LoNDON : A. H. BAILY \& CO., CoRNHILL. 
Advertisements.

BAILY'S SERIES OF DERBY WINNERS.

PRICE ONE GUINEA EACH.

\section{"IM A C A R O N I,"}

WTNNER OF THE

DERBY STAKES AT EPSOM, 1863.

Painted by HAREY HALL, and Engraved by HARRIS, beautifully Coluured after the Original Painting.

\section{" LORD CLIFDEN,"}

WLNER OF THE

GRAT ST. LEGER STAKES AT DONCASTER, 1863.

Puinted by HARRY HALL, and Engraved by HARRIS, beautifully Coloured after the Original Painting.

\section{"BLAIR ATHOL,"}

WINNER OF THE

DERBY STAKES AT EPSOM, 1864,

AND THE

GREAT ST. LEGER STAKES AT DONCASTER, 1864.

Fuinted by HARRY HALL, Engraved by HARRIS, and beautifully Coloured after the Original.

\section{"GLADIATEUR,"}

THE

WINNER OF THE DERBY, 1865,

TWO THOUSAND GUINEA STAKES, 1865, AND

ST. LEGER STAKES AT DONCASTER.

London: A. H. BAILY \& CO., CORAHILL. 


\section{Advertisements.}

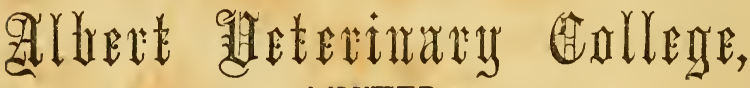 LIMITED,}

QUEEN'S STREET, BAYSWATER.

$$
\text { 艃restiont. }
$$

HIS GRACE THE DUKE OF NEWCASTLE.

Principal.

Professor JOHN GAMGEE.

Professor of Veterinary Anatomy, and Curator of Anatomical Inuseum.

JAMES LAW, M.R.C.V.S.

Professor of Veterinary Physiology.

WILLIAM DUGUID, M.R.C.V.S.

Professor of Veterinary Materia Medica, and

Superintendent of Pharmacy.

GEORGE ARMATAGE, M.R.C.V.S.

Professor of Chemistry.

WILLIAM J. RUSSELL, Ph.D., F.C.S.

Infirmary Superintendent and Professor of the Art of Farriery.

JOSEPH GAMGEE, Senr.

Professor of Veterinary Medicine and Surgery.

JOHN GAMGEE.

Professor of Agriculture.

JOHN COLEMAN,

Late Professor of Agriculture at the Royal Agricultural College, Cirencester.

Secretary.

Mr. R. B. PUNNETT.

Noblemen and Gentlemen can get any number of Horses examined for soundness and Sick Animals treated at the College Infirmary by paying an annual subscription of Two Guineas.

HHESS.

Perpetual Ticket for Winter Session : $\begin{array}{llll}. & £ 26 & 5 & 0\end{array}$

Single-class Ticket $. \quad . \quad . \quad . \quad . \quad 5 \quad 50$ 


\section{Advertisements.}

Second Edition, in demy 4 to, cloth, gilt edges, price 9 s.

\section{FELIX ON THE BAT:}

BEING A SCIENTIFIC NNQUTR INTO THE

\section{USE OF THE CRICKET BAT,}

TOGETHER WITH THE

\section{HISTORY AND USE OF THE CATAPULTA.}

A DISSERTATION ON THE DIFFERENT KINDS OF BOWLING,

With valuable suggestions as to the management of the Field when employed under the operation of Fast and Slow Bowling, and a scientific investigation into the vexata-questio of LEG BEFORE WICKET.

ALSO THE

\section{正alus of the Game,}

AS REVISED BY THE MARYLEBONE CLUB.

Illustrated with Seven Coloured Plates and Twenty-eight Woodruts and Diagrams.

The most comprehensive and important work on the art of Cricket ever published.

In foolscap 8vo, price $1 s$.

\section{THE ART OF SKATING} PRACTICALLT CONSIDERED.

galditly dibe glates.

Containing, in the simplest form, an explanation of the manner of forming twenty different evolutions on the ice.

LONDON : A. H. BAILY \& CO., CORNHILL. 


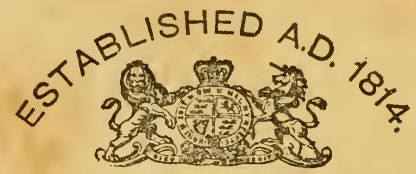

SIATIE IBIIIIAIRID

BY APPOINTMENT.

\section{MESSRS. THURSTON \& CO., BILLIARD TABLE MANUFACTURERS}

TO HER MAJESTY THE QUEEN,

His Royal Highness the Prince of Wales, The Right Honourable the Secretary of State for War, The Lords Commissioners of the Admiralty, Her Majesty's Regiments, \&c., \&c., \&c., 14, CATHERINE STREET, STRAND, LONDON ; AND SALISBCRY WHARF, ADELPHI, W.C.

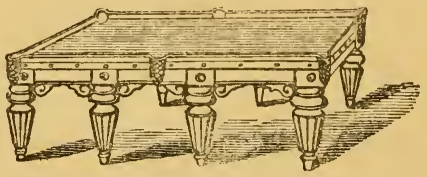

Messis. T. \& Co. have been patronized by Royalty since the time of George III., during which period they have been honoured by the patronage of the principal Nobility and Gentry of the United Kingdom, nearly two hundred and fifty of Her Majesty's and the Native Regiments at home and abroad, and more than One Hundred of the principal London, Provincial, and Foreign Clubs. Cloths of the finest texture-Balls of superior and well-seasmed Ivory turned on the truest Mechanical principles.

Inventors and Manufacturers of

\section{THE CENTRAL REVOLVING IAIP,}

The best Light ever constructed for Billiard Tables.

Patent Cement for Cue Tops, 1s., 1s.6d., and 2s. per Bottle.

\section{THE GAME OF BILLIARDS.}

By Edwin Kentfield, of Brighton.

London: Published by the Proprielors, Tucrston \& Co. 


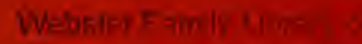
Comm is a not

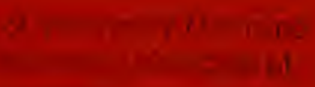
17,10

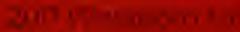
Muth or look the 01s83 
